Research Article

\title{
Irregularity Effects of Masonry Infills on Nonlinear Seismic Behaviour of RC Buildings
}

\author{
Massimiliano Ferraioli (i) and Angelo Lavino (i) \\ Department of Engineering, University of Campania "Luigi Vanvitelli", Via Roma 29, Aversa 81031, Italy \\ Correspondence should be addressed to Massimiliano Ferraioli; massimiliano.ferraioli@unicampania.it
}

Received 9 December 2019; Revised 13 April 2020; Accepted 21 May 2020; Published 29 June 2020

Academic Editor: Nicholas Alexander

Copyright (c) 2020 Massimiliano Ferraioli and Angelo Lavino. This is an open access article distributed under the Creative Commons Attribution License, which permits unrestricted use, distribution, and reproduction in any medium, provided the original work is properly cited.

\begin{abstract}
Despite extensive research studies, the seismic response of infilled reinforced concrete buildings remains an open problem due to both the complexity of the interaction between the infill and the frame and the large number of parameters involved. Thus, guidelines for both modelling and analysis are still lacking and the infill walls are normally treated as nonstructural components in seismic codes. However, it may be not conservative to neglect the influence of infills. In fact, the infill masonry walls may significantly affect the stiffness, strength, and energy dissipation capacity of RC buildings, even when they are regularly distributed. Recognizing this influence and its importance on the vulnerability of infilled frames, Eurocode 8 requires amplifying seismic action effects due to infills. In this paper, the effectiveness of the Eurocode 8 design provisions for infill irregularity in plan and/or elevation was investigated. To this aim, different in-plan layouts of infill walls were selected as marginal cases for which Eurocode 8 does not require amplification of the action effects due to the presence of infills, or the additional measures to counteract these effects are not mandatory. The seismic vulnerability of the infilled RC buildings was evaluated using nonlinear static and nonlinear dynamic analyses. Both cracking and crushing of masonry and stiffness and strength degradation were considered in the analysis. The effect of the layout of the masonry infills on the seismic response in terms of resistance and displacement was evaluated. Results show that in one of the case studies here examined, it is not conservative to neglect the influence of infill panels. In fact, structural failure due to torsion and soft-storey effects may occur even in cases where Eurocode 8 does not require the amplification of the action effects. Finally, the total shear demand on columns may be underestimated, even in cases where the code provisions for infills irregularity are not mandatory, and the additional shear demand in the columns induced by the masonry infill is very low.
\end{abstract}

\section{Introduction}

Reinforced concrete frames infilled with masonry walls are widely used for low-to-medium-rise buildings throughout the world, also including high seismicity zones. The use of unreinforced masonry infills as interior partitions and external walls is often the favourite solution since it matches all architectural needs, such as efficient thermal and sound insulation, durability, and simple and cost-effective construction. Experience from recent destructive earthquakes (Turkey Kocaeli earthquake in 1999, the Central Peru earthquake in 2007, the China Sichuan earthquake in 2008, L'Aquila earthquake in 2009, and the Emilia earthquake in 2012) has confirmed that the masonry infills may have a significant role in the seismic performance of RC buildings. In fact, the studies of postseismic damage have highlighted the vulnerability of irregularly infilled RC framed buildings and the need for better understanding of inelastic behaviour and failure mechanisms due to interaction between masonry infills and frame members. In the European seismic regions, the masonry panels are constructed in complete contact with the surrounding RC frame and are made of brittle materials. Therefore, they interact with the surrounding RC members and the combined effect of their high stiffness and brittleness may negatively affect the seismic performance of the structure. In fact, the uncertain position of the masonry infills walls together with the loss of integrity of some infills under cyclic loading can make the building irregular in plan and elevation. 
This occurrence is often produced when the ground floor is left open because of its usage for commercial purposes, while the other storeys are infilled. In this situation, severe localized damage or collapse of the first storey ("weak" or "soft" storey) may occur under strong earthquake ground motions $[1,2]$. On the other side, if the infill walls are irregularly distributed in plan, negative torsional effects may be induced and thus the inelastic deformation demands concentrate on the "flexible" side of a building (i.e., the part in which there are fewer partitions). Nowadays, it is generally recognized that the interaction between masonry infills and reinforced concrete structures plays a critical role in seismic performance of buildings since their contribution to seismic resistance of RC buildings might not be beneficial. In fact, the stiffness and strength of masonry infills might preserve the building from structural damage but also result in unintended and unwanted effects. First of all, the increased stiffness of the infilled frames increases the natural frequency, thus influencing the seismic demand $[3,4]$. Then, acting as diagonal struts, the masonry infills cause additional internal forces at the ends of beams and columns and increase the seismic shear forces at the beam-column joints. This occurrence might activate brittle failure modes under cyclic loading, undesirable softstorey failure, or short column effect, especially for buildings designed without seismic provisions. Finally, the irregular distribution of masonry infills in plan and elevation might induce undesirable soft-storey failure, short column, or additional torsional effects, thus increasing damage even under moderate earthquake ground motions.

The seismic behaviour of masonry infilled RC buildings was investigated since the 1950s. Many experimental studies were carried out to investigate the interaction of infill walls with the RC frame structure. On the other side, several research studies developed analytical models of masonry infill panels going from pinned equivalent struts macromodelling to finite element micromodelling for the performance analysis under both monotonic and cyclic loads. However, many problems remain unresolved and questions are left open, and this makes it difficult to account for the effects of masonry infills in current practice. The first reason for this is because the interaction between brittle materials such as masonry and concrete is difficult to model for its high degree of nonlinearity and degradation. Then, a wide scatter of published experimental data was observed. On the other side, the existing analytical models are generally formulated and validated based on experimental data, but they cannot be readily relied upon since their many parameters need a great effort. Moreover, it is difficult to generalize the results since they depend on overall geometry of infills and their distribution in plan and elevation, location and dimension of openings, methods properties of infill and concrete members, reinforcement configurations, and construction details. Finally, there is a lack of standardized guidelines for modelling masonry infill panels in global seismic analysis of buildings. On the other side, more studies are required that focus on the role of masonry infills in the seismic performance of RC buildings. Mehrabi et al. [5] investigated the influence of masonry infill panels on the seismic performance of RC frames designed following the current code provisions. Panagiotakos and Fardis [6] studied the effects of masonry infills on the global seismic response of reinforced concretes structures. Dolšek and Fajfar [7] studied the effect of masonry infills on the seismic response of a four-storey reinforced concrete frame using the N2 method. Many case studies were presented about the influence of the infill panels over the seismic response and failure mechanisms of infilled RC buildings with different infill configurations [8-10] and the effects of vertical irregularity and thickness of masonry infills on the robustness of structures [11]. Asteris et al. [12] classified the collapse of infilled frames into five distinct modes (corner crushing, diagonal compression, sliding shear, diagonal cracking, and frame failure). The additional shear demand of the columns due to the local frame-infill interaction may cause their brittle shear failure. To account for this effect, Celarec and Dolšek [13] proposed an iterative pushover-based procedure to approximately incorporate the effects of masonry infills on the shear demand of the columns and simulate their brittle failure modes for the case when infills are modelled by means of simplified nonlinear models. Cavaleri and Di Trapani [14] proposed to calculate the axial load transferred as shear to each section through the use of shear distribution coefficients estimated through an extended numerical experimentation on infilled frames with different characteristics. Mohammad et al. [15] showed the importance of accounting for shear failure of columns when modelling the infill-frame interaction and the influence of the inelastic shear law. Basha and Kaushik [16] improved the existing strut modelling by simulating the effect of infill on columns to account for the increased shear demand on the column because of the frame-infill interaction. Several factors were found to affect the failure mechanism, including type of infill and construction method, aspect ratio and openings of masonry panel, number of stories and bays, column-to-beam stiffness ratio, and axial load ratio on columns. Despite the large number of studies in the literature, the issue related to modelling and analysis of masonry-infilled RC structures remains unresolved, and there is a need for more research on the subject.

This paper investigates the effectiveness of the Eurocode 8 design provisions for infill irregularity in plan and/or elevation. To this aim, the paper addresses marginal cases in which Eurocode 8 does not require any measures for infilled frames, or the additional measures are not mandatory. Thus, a numerical campaign on infilled frames structures with different kinds of infills was carried out. A multistrut macromodel including the classical truss elements and a special shear frictional strut was used to reproduce the frame-infill interaction. A series of nonlinear analyses were carried out to evaluates the effect of unreinforced masonry infill walls on seismic performance, failure modes, hysteresis behaviour, and force transfer mechanisms of the building. The obtained results provide useful insights into the accuracy and conservativeness of Eurocode 8 design provisions for infill irregularity in plan and elevation.

\section{Design Provisions for Infilled RC Frames in Seismic Codes}

In general design practice of new buildings, designers usually treat the masonry infill panels as nonstructural elements and 
do not include their contribution in both the analysis model and the design procedure. The masonry infills are only considered as appropriately distributed additional loads and masses, while the local and global effect due to the interaction of these stiff and brittle elements with the RC bare frames is neglected. This means that the real seismic performances of the building may differ considerably from those predicted using the structural model, especially when the building is subjected to strong ground motions. On the other side, the retrofit of existing buildings is based on a preliminary estimate of their seismic safety based on nonlinear static analysis. The pushover curve of the infilled frame can be very different from that of the corresponding bare frame. In fact, the masonry infills can significantly enhance the capacity of the existing buildings to resist lateral forces, but, on the other side, the infill irregularity in plan and elevation can increase the seismic action effects. The design procedures differ significantly from one country to another due to the complexity of infill-frame interaction. In many cases, the current seismic codes do not give detailed provisions but only generic recommendations for nonstructural elements. In particular, they do not adequately consider the role of the masonry infill panels in the seismic response of buildings. Eurocode 8 [17] does not require explicit considerations of infills as structural members. Thus, infilled RC frames are analysed as if they were bare frames. However, the design process tries to eliminate all of the potential adverse effects due to masonry infills, while their beneficial effects are conservatively neglected. Practically, the code provisions counteract the potential adverse effects depending on plan and elevation irregularity of the masonry infills. The irregularities in the distribution of infills in plan are considered by increasing the accidental eccentricity by a factor equal to 2.0. As far as the distribution of infills over the structural height, regularly distributed infills may significantly reduce the deformation demand and enhance the energy dissipation capacity of the building under earthquake ground motions. On the contrary, irregular distributed infills may give high seismic demand of inelastic deformations and brittle failure modes due to torsion and softstorey effects. In case of regularly infilled frames, all the global effects due to masonry infills (stiffening/strengthening and nonapparent soft-storey effects) can be conservatively neglected, while the local shear effect should be considered. The stiffening/strengthening effect can be neglected because the increasing of seismic forces demand is compensated by the increasing strength due to infills [18]. The nonapparent soft-storey effect occurs when the masonry infills in a particular storey fail prior to those in the others under earthquake ground motion, thus creating a soft/weak storey irregularity [19]. This effect can be neglected in case of regularly infilled frames since the lateral drift demands of regularly infilled frames tend to concentrate in lower stories where it is kept well below that required to trigger structural instability [18]. In case of irregularities in elevation of infills, the seismic action should be amplified by the magnification factor. The Italian Code $[20,21]$ recommends magnifying forces in potentially soft stories, multiplying by a fixed magnification factor of 1.40. According to Eurocode 8 [13], the calculated seismic action effects should be amplified by a magnification factor $\eta$ defined as follows:

$$
\eta=\left(1+\frac{\Delta V_{\mathrm{Rw}}}{\Sigma V_{\mathrm{Ed}}}\right) \leq q
$$

where $\Delta V_{\mathrm{Rw}}$ is the total reduction in lateral resistance of masonry infill walls in the storey concerned, compared to the more infilled storey above it, $\Sigma V_{\mathrm{Ed}}$ is the sum of the seismic shear forces acting on all structural vertical elements of the storey concerned, and $q$ is the behaviour factor. The American technical codes [22-24] suggest using a macromodelling approach for the analysis of infilled frame structures, modelling infill as an equivalent diagonal compression strut having the same thickness and Young's modulus of the masonry infill and an equivalent width estimated using the relationship proposed by Mainstone [25]. However, general information about the evaluation of the mechanical properties of the masonry infills and the influence of vertical loads on the lateral stiffness of masonry infilled frames are still lacking. Moreover, provisions are not provided for infilled frames with openings. Finally, FEMA 356 [26] allows to calculate the masonry infill in-plan stiffness and strength, based on nonlinear finite element analysis of a composite frame substructure with infill panels that account for the presence of openings and postyield cracking of masonry. Alternatively, general provisions are given about the elastic in-plan stiffness, strength, and deformation capacity of solid and perforated masonry infills, as well as the corresponding acceptance criteria.

\section{Modelling of Masonry Infills}

3.1. Review of Models for Infilled Frame Structures. The analytical modelling of infilled frame structure is a very complex issue since the interaction of the masonry infill panel and the surrounding frame gives rise to a highly nonlinear inelastic behaviour due to the bare frame (cracking of concrete, yielding of steel reinforcing bars and bond slip), the masonry infills (cracking and crushing, stiffness and strength degradation) and the panel-frame interfaces (variation of the contact length and degradation of the bond-friction mechanism). Moreover, very limited experimental tests were performed on real-scale infilled RC frames and the experimental research in the literature refers only to selected masonry typologies, like clay bricks and concrete blocks. The first studies on framed structures infilled with unreinforced masonry walls began since the 1950s. Poyakov [27] proposed a model in which the effect of the infill walls is represented as an equivalent compression only brace. Holmes [28] first proposed the empiric rule to replace the panel with an equivalent diagonal strut, with cross section width equal to $1 / 3$ of the diagonal length. Smith [29] calibrated a relationship to evaluate the relative panelto-frame stiffness using experimental results on several infilled steel frames. Mainstone [25] suggested an empirical equation based on experimental and analytical data to estimate the equivalent strut width $w$ : 


$$
\frac{w}{d}=0.175 \cdot \lambda_{n}^{-0.4},
$$

where $d$ is the diagonal length of the masonry panel and $\lambda_{n}$ is the relative panel-to-frame stiffness introduced by Smith [29]. This is one of the most popular formulations since it was included in FEMA-274 [23] and FEMA-306 [30]. Klingner and Bertero [31] presented the first experimental and analytical studies on the cyclic behaviour of infilled frames structures also providing a first hysteretic model. Afterwards, many other studies in the literature proposed more detailed models to predict the interaction effects between frames and infills. Such methods may be divided roughly into two categories, depending on whether they are based on micromodelling or macromodelling approaches. The former is based principally on the Finite Element Method and requires the modelling of both the masonry blocks and mortar joints as discrete elements and the interface as continuous links to reproduce the shear sliding of masonry mortar. The latter simulates the infill behaviour with equivalent diagonal struts and it is less complex and computationally demanding, even though unable to capture local phenomena. A complete literature review about the aforementioned approaches was carried out by Asteris et al. [32] and Crisafulli et al. [33]. Saneinejad and Hobbs [34] described a new method of analysis and design for steel frames with concrete or masonry infilling walls subjected to in-plan forces. Madan et al. [35] proposed an analytical macromodel based on an equivalent diagonal strut approach with a hysteretic force-deformation rule that accounts for strength and stiffness degradation as well pinching resulting from opening and closing of masonry gaps. Crisafulli et al. $[36,37]$ proposed a simplified macromodel, which considers two pairs of compression-tension diagonal struts to carry axial loads and two pairs of shear struts to carry the shear from the top to the bottom of the panel. El-Dakhakhni et al. [38] presented a simple method in which each masonry panel is replaced by three struts with force-deformation characteristics based on the orthotropic behaviour of the masonry infill. The multiple strut approach is useful to account for the shear transmission in critical regions. However, the calibration of the related parameters may be somewhat complex. Cavaleri et al. [39] proposed a detailed force-displacement law accounting for cyclic or monotonic behaviour taking the results of experimental tests into account.

\subsection{Nonlinear Modelling and Calibration of Infill Panel} Parameters. In this paper, the masonry infills were modelled using the macromodel proposed by Crisafulli et al. [36, 37], which considers both frictional effects and local infill-frame interaction and accounts for the different failure modes. The model is based on two parallel compression-tension diagonal struts in each diagonal direction to carry the axial loads and a shear strut to carry the shear from the top to the bottom of the panel (Figure 1). A hysteresis model is used for the axial struts while a bilinear model is considered for the shear strut. In Figure 1, the vertical and horizontal offsets are used to account for the dimensions of the masonry panel that depend on the depth of the frame members. This model is probably one of the most complete macromodels for masonry. However, a great number of parameters difficult to characterize should be evaluated for its application [36]: elastic modulus $\left(E_{\mathrm{mo}}\right)$, compressive strength $\left(f_{n}\right)$, tensile strength $\left(f_{t}\right)$, strain at max stress $\left(\varepsilon_{m}\right)$, ultimate strain $\left(\varepsilon_{u}\right)$, closing strain $\left(\varepsilon_{\mathrm{cl}}\right)$, unloading stiffness factor $\left(\gamma_{\mathrm{un}}\right)$, reloading strain factor $\left(\alpha_{\mathrm{re}}\right)$, strain inflection factor $\left(\alpha_{\mathrm{ch}}\right)$, complete unloading strain factor $\left(\beta_{a}\right)$, stress inflection factor $\left(\beta_{\mathrm{ch}}\right)$, zero-stress stiffness factor $\left(\gamma_{\mathrm{plu}}\right)$, reloading stiffness factor $\left(\gamma_{\mathrm{plr}}\right)$, plastic unloading stiffness factor $\left(e_{x 1}\right)$, repeated cycle strain factor $\left(e_{x 2}\right)$, shear fraction $\left(\gamma_{s}\right)$, friction coefficient $(\mu)$, bond shear strength $\left(\tau_{o}\right)$, and reduction shear factor $\left(\alpha_{s}\right)$. These parameters were calibrated using past experimental data in literature [40]. In particular, the test for the ductile RC frame infilled with full-scale fly ash bricks $(230 \times 110 \times 75 \mathrm{~mm})$ was used for calibration. The test named DFS in [40] was carried out on infill constructed using $1: 4$ (cement:sand) mix mortar with a water cement ratio of 0.6. The infill wall was constructed by laying bricks in stretcher bond (running bond). The calibration was carried out using SeismoStruct software [41]. The default values recommended by Smyrou et al. [42] were used as the first trial. The maximum value of base shear force was used to correct the vales of initial Young's modulus and compressive strength. The parameters $\gamma_{\mathrm{un}}, \alpha_{\mathrm{ch}}$, and $e_{x 1}$ that control the shape of hysteresis loops were changed in the range provided by Crisafulli [36] to match the experimental results. Finally, the values of the less influential parameters were modified to reduce the differences in both pinching and strength degradation. Figure 2 shows the lateral load behaviour of specimens during slow cyclic loading in the form of hysteretic response. The numerical hysteresis loops after the calibration of infill panel model are compared with experimental data. The values of calibrated parameters are shown in Table 1. These values were used in the analysis, while the geometrical parameters were updated according to the geometry of the structure.

It should be highlighted that most past studies $[13,43-46]$ used fly ash or solid clay bricks, hollow blocks, or concrete bricks/blocks as infills. In the current study, frames were infilled with fly ash bricks, which were found to be considerably softer and weaker compared to the RC frame [47]. Similar to past studies $[48,49]$, this low-strength masonry was used in order to reduce the effect of infill on the lateral load response of the frames and the shear demand on the columns due to the frame-infill interaction. The reason of this choice is that this paper mainly focuses on evaluating the effectiveness of Eurocode 8 design provisions in marginal cases for which the amplification of the action effects due to the presence of infills is low or absent.

\subsection{Nonlinear Modelling of RC Members. A three-storey} regular RC frame building was considered in the analysis. Figures 3 and 4 show the plan and 3D view of the building considered in the analyses. The storey height is $3.5 \mathrm{~m}$ for the first floor and $3.0 \mathrm{~m}$ for the other ones. The bay length is $5.00 \mathrm{~m}$ in both orthogonal directions. The slab is $20 \mathrm{~cm}$ thick. 


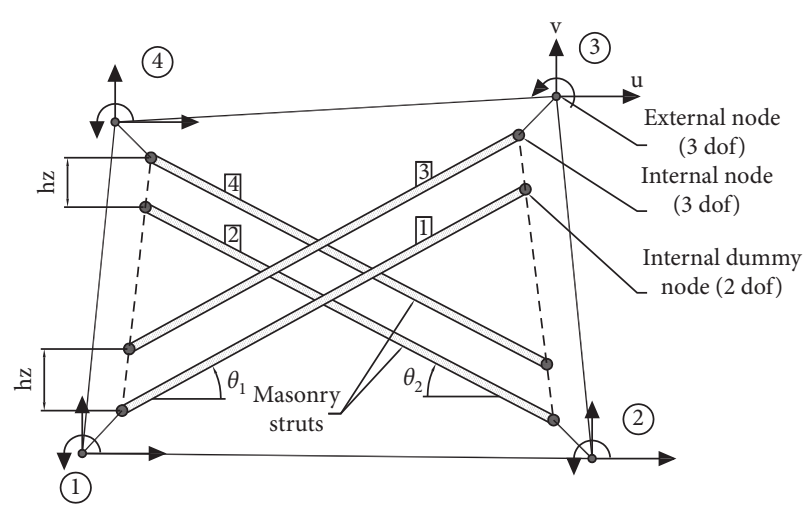

(a)

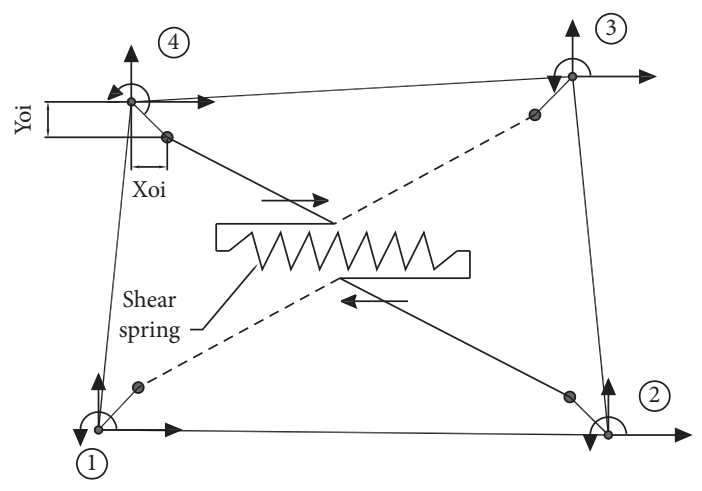

(b)

Figure 1: Four-node masonry panel model proposed by Crisafulli [32].

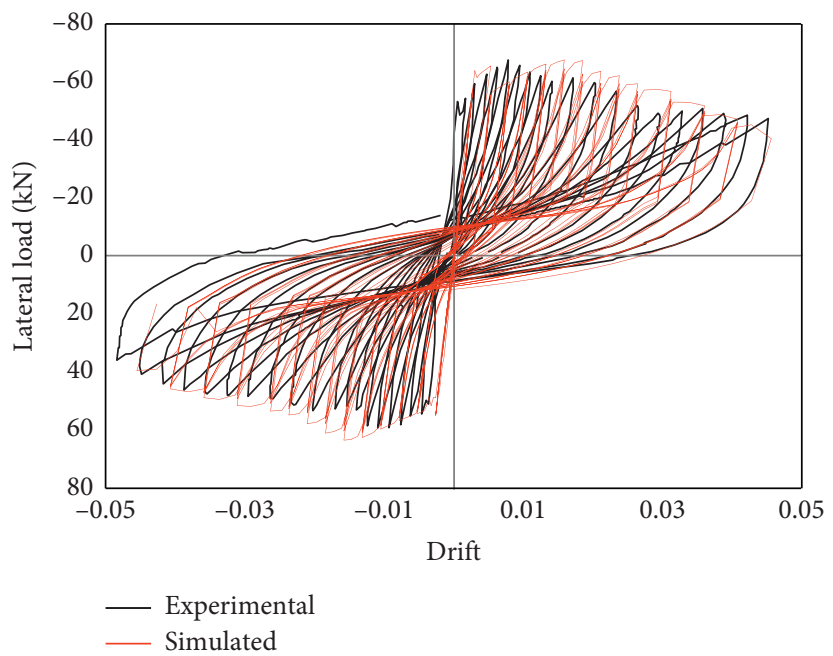

Figure 2: Force-displacement hysteresis curves during slow cyclic loading. Experimental hysteresis loop vs. simulated hysteresis loop.

TABLE 1: Calibrated values of parameters of masonry infill panels.

\begin{tabular}{lc}
\hline Elastic modulus $E_{\mathrm{mo}}(\mathrm{kPa})$ & 1158000 \\
Compressive strength $f_{n}(\mathrm{kN})$ & 680 \\
Tensile strength $f_{t}^{\prime}(\mathrm{kN})$ & 0.5 \\
Strain at max stress $\varepsilon_{\mathrm{m}}$ & 0.004 \\
Closing strain $\varepsilon_{\mathrm{cl}}$ & 0.04 \\
Unloading stiffness factor $\gamma_{\mathrm{un}}$ & 1.6 \\
Reloading strain factor $\alpha_{r e}$ & 0.48 \\
Strain inflection factor $\alpha_{\mathrm{ch}}$ & 0.90 \\
Complete unloading strain factor $\beta_{a}$ & 0.99 \\
Stress inflection factor $\beta_{\mathrm{ch}}$ & 1.4 \\
Zero-stress stiffness factor $\gamma_{\mathrm{plu}}$ & 0.7 \\
Reloading stiffness factor $\gamma_{\mathrm{plr}}$ & 1.7 \\
Plastic unloading stiffness factor $e_{x 1}$ & 3.2 \\
Repeated cycle strain factor $e_{\mathrm{x} 2}$ & 1.7 \\
Shear fraction $\gamma_{s}(\mathrm{kN})$ & 140 \\
Friction coefficient $\mu$ & 0.9 \\
Bond shear strength $\tau_{\mathrm{o}}(\mathrm{kN})$ & 250 \\
Reduction shear factor $\alpha_{s}$ & 1.8 \\
\hline
\end{tabular}

The steel material used is B450C having tensile strength value equal to $450 \mathrm{MPa}$. The cross-sections are $40 \times 40$ for columns and $40 \times 50$ for beams. The concrete is assumed to have a nominal compressive strength $f_{\text {ck }}=25 \mathrm{~N} / \mathrm{mm}^{2}$ (compressive strength class $\mathrm{C} 25 / 30$ ) and a unit weight of $24.0 \mathrm{kN} / \mathrm{m}^{3}$. The building was designed and detailed according to Eurocode 8 [17] for site class A, Ductility Class Medium (DCM), and behaviour factor $q=3.9$ for the ultimate limit state verifications. The design spectral acceleration was evaluated considering damping ratio $5 \%$ and design Peak Ground Acceleration of $0.25 \mathrm{~g}$ for the Life-Safety Limit State. The design base shear was equal to $0.16 \mathrm{~W}$, where $W$ is the seismic weight of the building. The seismic effects were calculated using the response-spectrum mode superposition method. The additional measures for masonry infilled frames presented in Section 4.3.6 of Eurocode 8 [17] were not applied, since they are not mandatory in the design of frame systems of Ductility Class Medium (DCM). In fact, Eurocode 8 considers the RC buildings of the lower ductility classes (Ductility Class Medium and Low) as designed for sufficient lateral strength to overshadow the infill walls. In this way, this study may address marginal cases in which Eurocode 8 does not require any measures for infilled frames. The capacity design provisions were applied to obtain the hierarchy of resistance. Meeting this criterion 


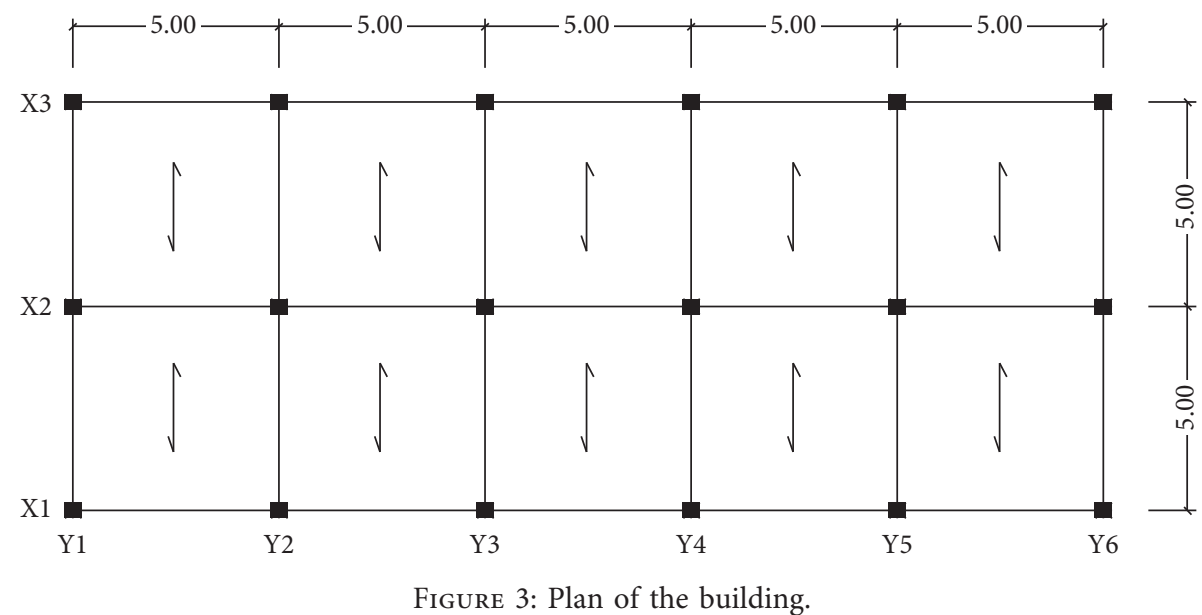

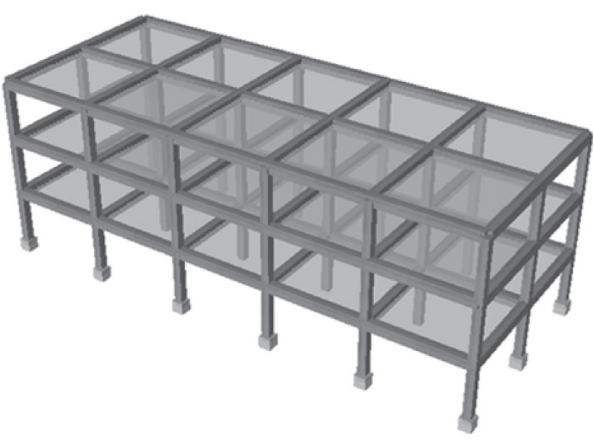

Figure 4: 3D view of the building.

results in high longitudinal reinforcement ratio for columns $\left(\rho_{l}>2 \%\right)$. The design longitudinal reinforcement is composed of $16 \phi 18$ for the corner columns and $18 \phi 18$ for the other columns. The transverse reinforcement consists of $8 \mathrm{~mm}$ diameter closed stirrups spaced at $10 \mathrm{~cm}$. Regarding the beams, the longitudinal reinforcement is composed of $4 \phi 14$ both on top and bottom. The transverse reinforcement consists of $8 \mathrm{~mm}$ diameter closed stirrups spaced at $15 \mathrm{~cm}$. In the numerical analysis, the following material parameters were used for concrete: null tensile strength, modulus of elasticity of $31476 \mathrm{MPa}$, and strain at peak stress of 0.002 . It was assumed for steel a modulus of elasticity of $210000 \mathrm{MPa}$, strain hardening parameter of 0.005 , fracture/buckling strain of 0.1 , and specific weight of $78 \mathrm{kN} / \mathrm{m}^{3}$. The RC structural members were modelled in SeismoStruct [41] using the inelastic force-based fibre elements (infrmFB). The cross section is subdivided into fibres of three materials: steel for reinforcing bars, confined concrete inside the inner layer of hoops, and unconfined concrete outside the hoops. A bilinear hysteretic model was used for the reinforcing steel bars, while the well-known Mander model [50] was used for confined concrete. Sections were assumed to behave elastically under shear and torsion.

\section{Parametric Study}

The RC structures can have various kinds of configurations of masonry infills. In order to investigate the influence of masonry infills on the seismic behaviour of infilled RCframe structures, both the presence and the absence of all infills, as well as different in-plan layouts of infill walls, were examined. To this aim, six case studies with different layouts of infills both regular and irregular in plan and/or elevation were considered in the analysis (Figure 5): (A) infills in two sides of the perimeter; (B) infills in one side of the perimeter; (C) infills in two sides at the first floor; (D) infills in one side at the first floor; (E) infills in two sides except in the first floor; and (F) infills in two sides at the first and third floors. As aforementioned, the plan and elevation irregularities due to masonry infill walls may change the seismic behaviour of the building with respect to those expected during the design phase. The asymmetric distribution of the masonry infill walls in plan (such as in case studies B and D) increases the eccentricity between the centre of mass and the centre of stiffness, thus generating additional torsional and higher modes effects during the seismic event. The irregular distribution of masonry infill walls over the height of the building (such as in case studies C, D, E, and F) may induce soft-storey collapse mechanisms in the storeys where infills are missing. It should be highlighted that some of the presented cases of infilled frames may not be entirely realistic buildings. However, it should be highlighted that the purpose of this paper is an analysis of the marginal cases for which Eurocode 8 does not require amplification of the action effects, or the additional measures are not mandatory, or the magnification factor due to infills is not able to counteract the potential adverse effects depending on the irregularity of the masonry panels. For this purpose, two different models were considered for each case study: (1) infill frame model and (2) bare frame model. The first one (infill frame model) explicitly considers the masonry infill panels using the macromodel described in Section 3.2. The second one (bare frame model) neglects the stiffness and strength contributions of the masonry infills and applies the Eurocode 8 provisions [17] for the infilled frames.

The seismic behaviour of the building was carried out using both static and dynamic inelastic procedures. The Nonlinear Static Procedures (NSPs) are widely used in the literature to estimate the deformation demands without the complex modelling and computational effort of Nonlinear 


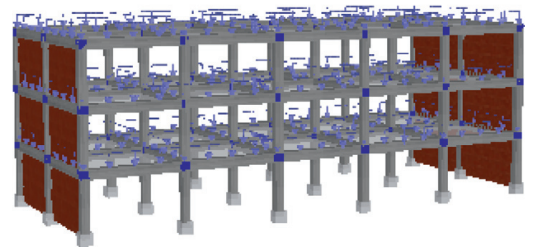

(a)

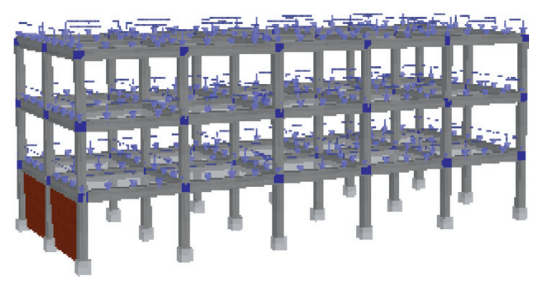

(d)

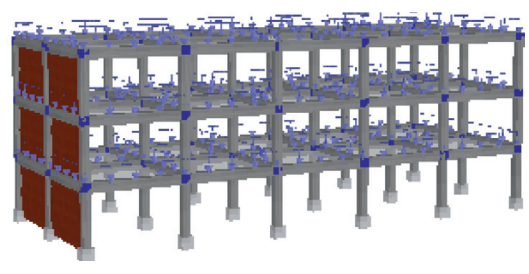

(b)

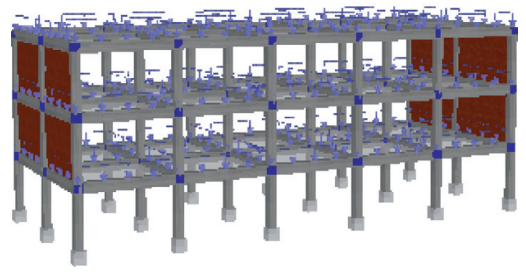

(e)

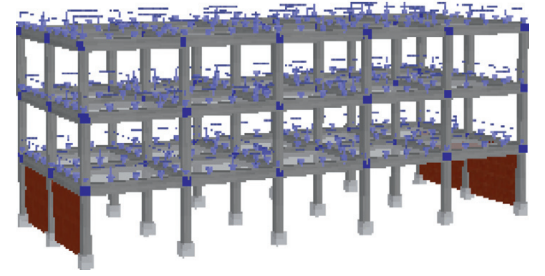

(c)

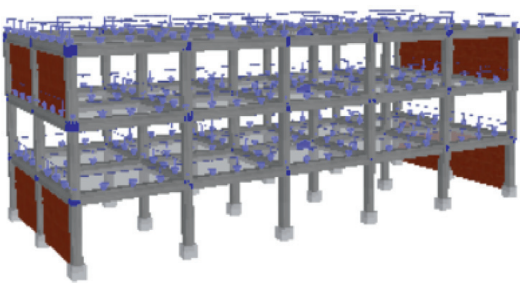

(f)

FIGURE 5: Different layouts of masonry infills considered in the analysis.

Response History Analysis (NRHA). Some NSPs based on the Capacity Spectrum Method or the Displacement Coefficient Method were incorporated in the current generation of seismic codes. The two main weaknesses of these conventional NSPs are the simplifying hypotheses they are based on: (1) the vibration properties remain unchanged in spite of structural yielding; (2) only the fundamental mode of vibration is considered, neglecting the effect of higher modes. Thus, modifications and improvements were proposed in the literature to include the higher mode effects [51-55], the progressive stiffness degradation [56-58], and the effects of masonry infills on reinforced concrete frames $[13,59]$. Since the main goal of this paper was to investigate the effectiveness of the code provisions for the infilled frame, the nonlinear static (pushover) analysis was carried out according to Eurocode 8 [17]. Thus, two vertical distributions of lateral loads were applied: (1) uniform pattern, based on lateral forces that are proportional to mass and (2) modal pattern, proportional to lateral forces consistent with the lateral force distribution determined in elastic analysis. The relation between base-shear force and control displacement (the "capacity curve") was determined according to EC8 provisions [17]. The procedure reported in Annex B of EC8 [17] was applied to calculate the target displacement. As it is well known, this procedure (that implements the N2 method [60]) is based on the elastoplastic idealization of capacity curve and the $R_{\mu}-\mu$-Trelation proposed by Vidic et al. [61] to scale the Elastic Demand Response Spectrum (EDRS) and plot the Inelastic Demand Response Spectrum (IDRS). In general, the extension of the $\mathrm{N} 2$ method to infilled RC frames requires a multilinear idealization of the pushover curve and a specific $R_{\mu}-\mu$-T relation. Dolšek et al. [62] developed an incremental N2 method to calculate the seismic demand of infilled reinforced concrete frames for multiple levels of seismic intensity. For the case studies examined in this paper, a specific $R_{\mu}-\mu-T$ relation is not required for the infilled frame structure. In fact, as will be highlighted below, no strength deterioration of pushover curves was observed. Thus, the traditional N2 method may be employed as a simple tool to estimate the Peak Ground Acceleration (PGA) for the LS Limit State $\left(\mathrm{PGA}_{\mathrm{LS}}\right)$. In fact, the target displacement corresponding to seismic capacity at Life Safety Limit State is known. In the same way, the effective period T, the ductility $\mu$ of the elastoplastic idealization of the capacity curve, and the corresponding reduction factor $R_{\mu}(T, \mu)$ are known. Thus, the N2 method may be used to calculate the elastic spectral acceleration that leads the structure to its LS Limit State and the corresponding Peak Ground Acceleration $\left(\mathrm{PGA}_{\mathrm{LS}}\right)$. Practically, this gives a point of the IN2 curve [62] corresponding to LS Limit State.

\section{Results and Discussion}

Figures 6 and 7 show the demand vs. capacity comparison in ADRS format (i.e., spectral acceleration $S_{a}$ vs. spectral displacement $S_{d}$ ) using the infill frame model for the different case studies (A-E) and lateral force distributions (i.e., first mode and uniform). Figures 8 and 9 show the results from the bare frame model. It should be underlined that in the case studies considered here the resistance of the masonry walls described in Section 3.2 is not so high. Thus, the magnification factor $\eta$ defined by (1) is less than 1.1 and, therefore, the calculated seismic action effects should not be amplified even in case of irregularity in elevation (i.e., C, D, $\mathrm{E}$, and F). On the other side, according to EC8 provisions [17], the irregularity of infills in plan (e.g., B and D) may be considered by increasing the accidental eccentricity by a factor equal to 2.0. Thus, Figures 8 and 9 show the results obtained using an accidental eccentricity of $5 \%$ and $10 \%$, respectively.

The capacity spectrum was obtained from the pushover analysis in the $Y$-direction with accidental eccentricity. Two performance points are plotted on the capacity spectrum corresponding to the Damage Limitation (DL) Limit State and Life Safety (LS) Limit State, respectively. The Limit State of Damage Limitation (DL) is defined by the chord rotation at yielding $\left(\theta_{y}\right)$ evaluated by the formulae (A.10b) and (A.11b) from EN 1998-3 [63]. The Limit State of Life Safety 


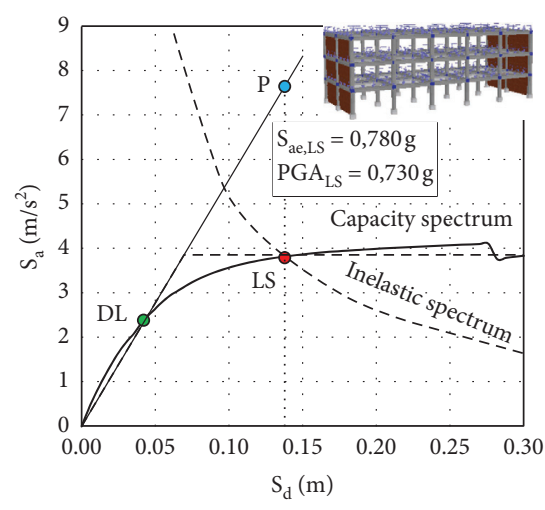

(a)

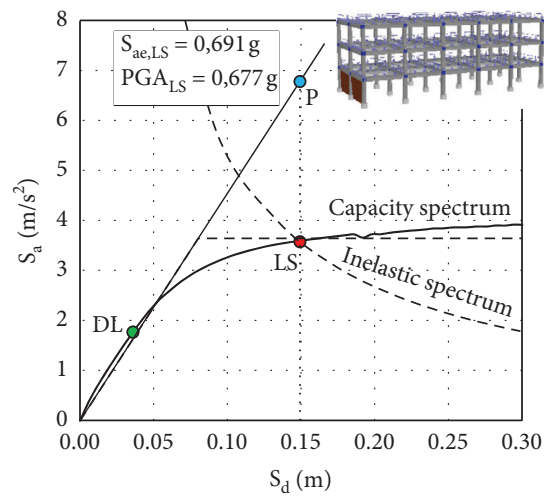

(d)

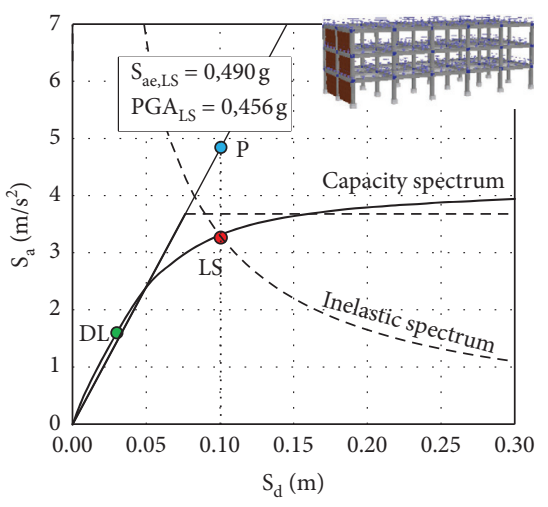

(b)

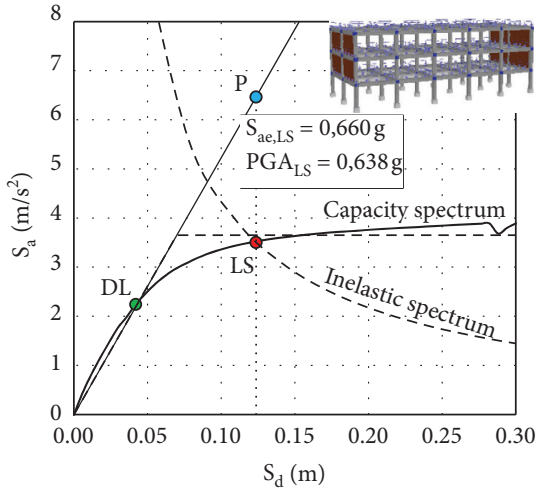

(e)

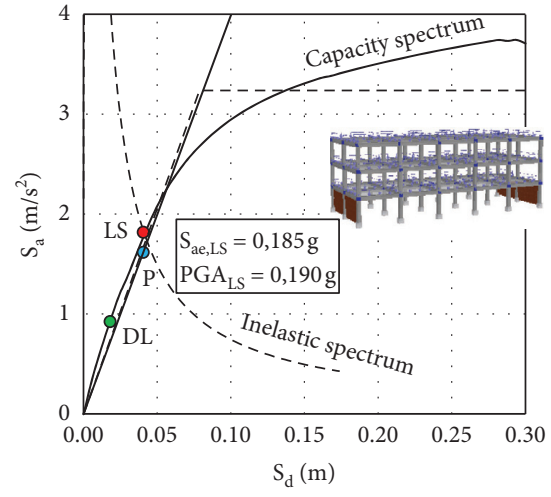

(c)

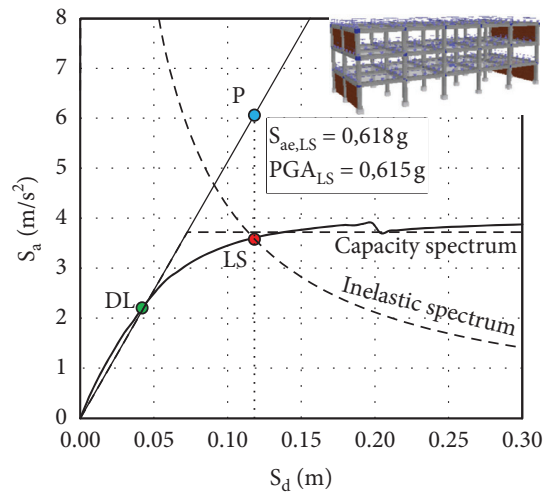

(f)

Figure 6: Demand vs. capacity comparison. Infilled frame model under uniform distribution. LS Limit State and corresponding elastic spectral acceleration $\mathrm{S}_{a e, \mathrm{LS}}$ and Peak Ground Acceleration $\left(\mathrm{PGA}_{\mathrm{LS}}\right)$.

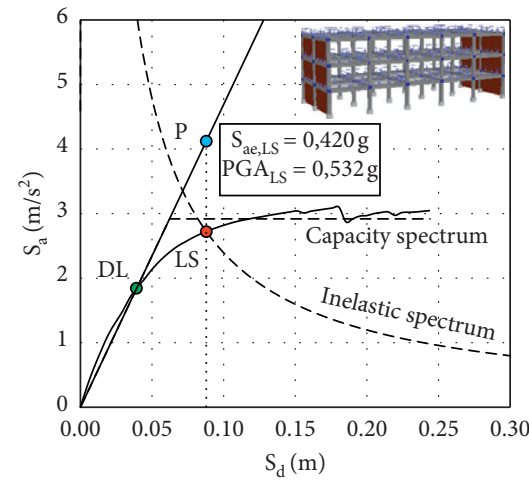

(a)

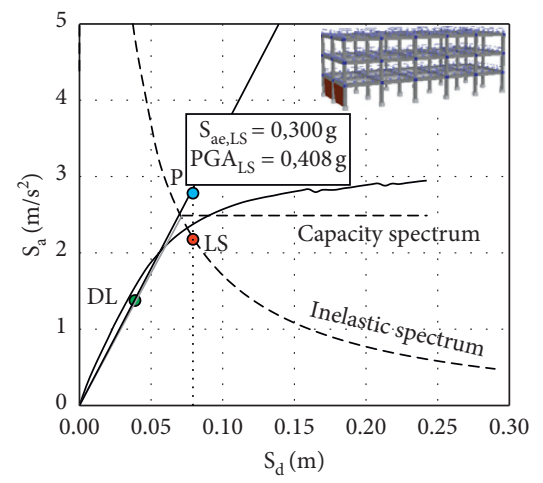

(d)

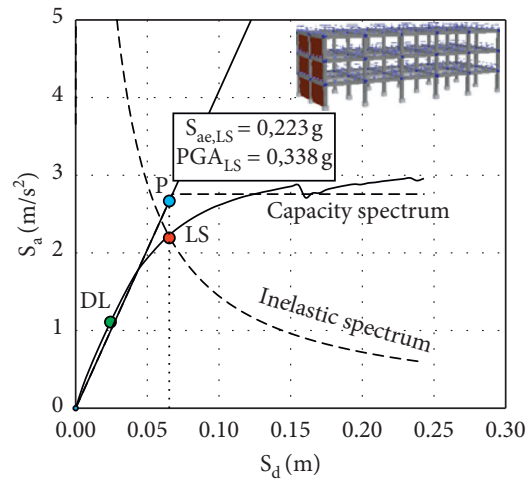

(b)

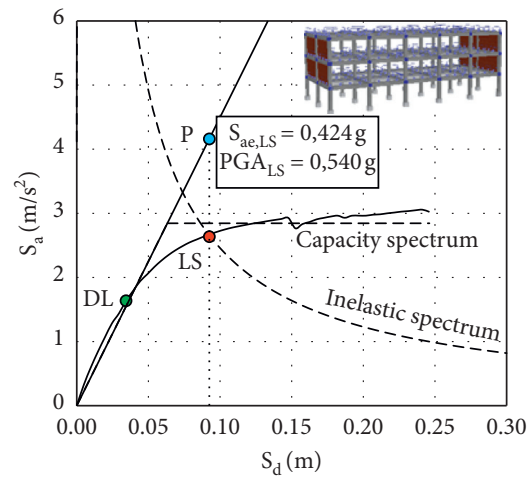

(e)

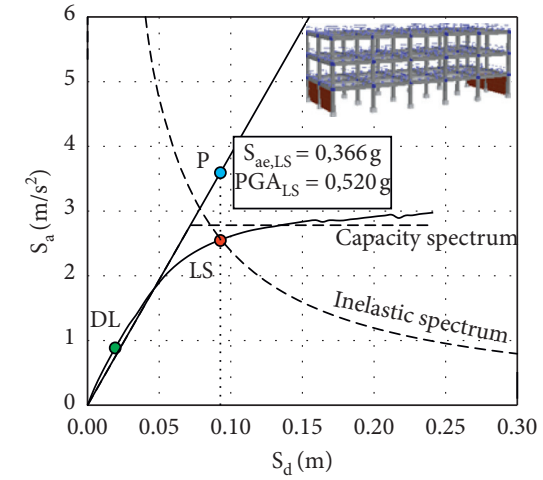

(c)

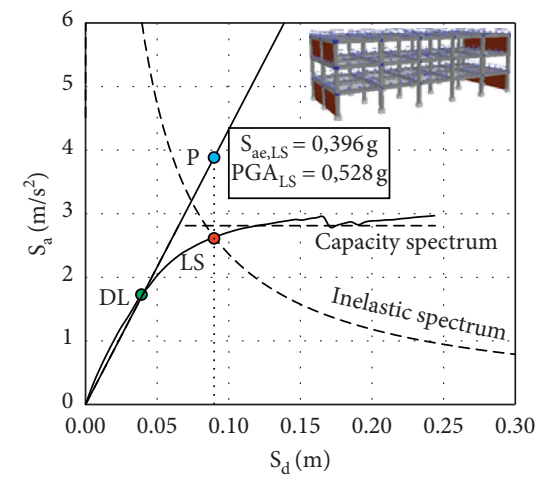

(f)

Figure 7: Demand vs. capacity comparison. Infilled frame model under first mode distribution. LS Limit State and corresponding elastic spectral acceleration $S_{a e, \text { LS }}$ and Peak Ground Acceleration PGA LS. 


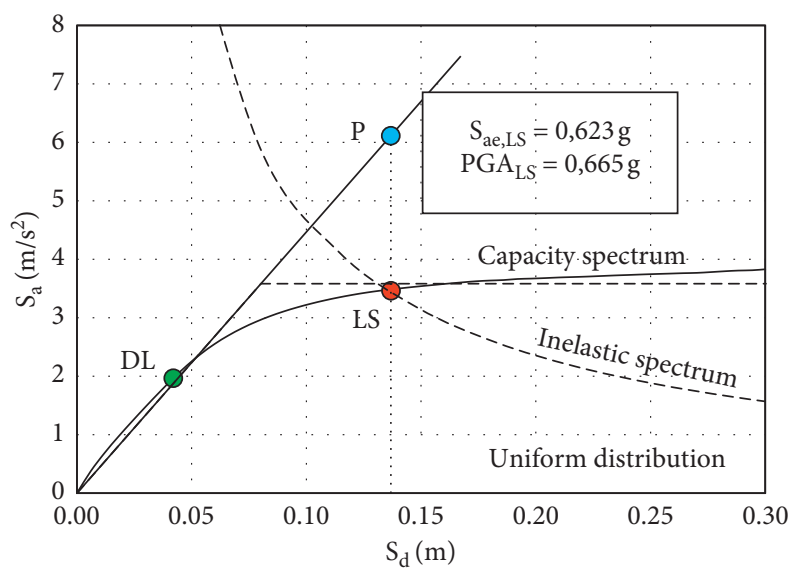

(a)

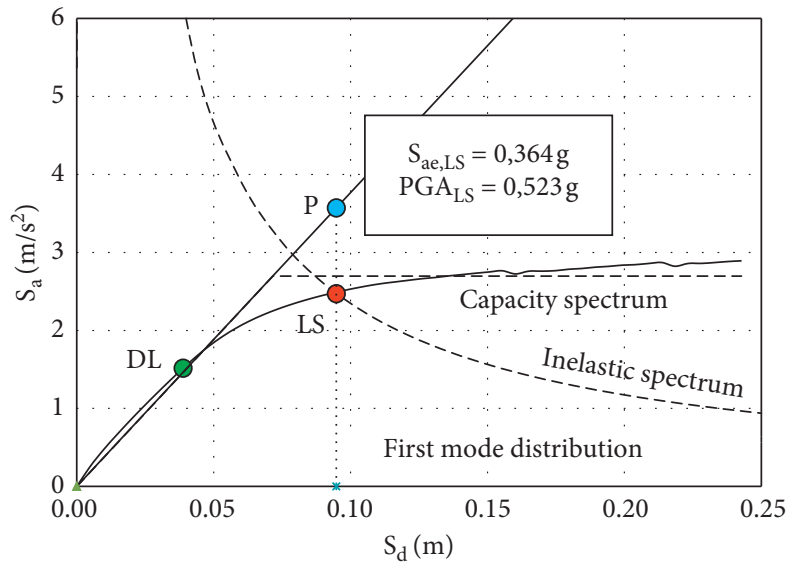

(b)

Figure 8: Demand vs. capacity comparison. The bare frame model with an accidental eccentricity of $5 \%$.

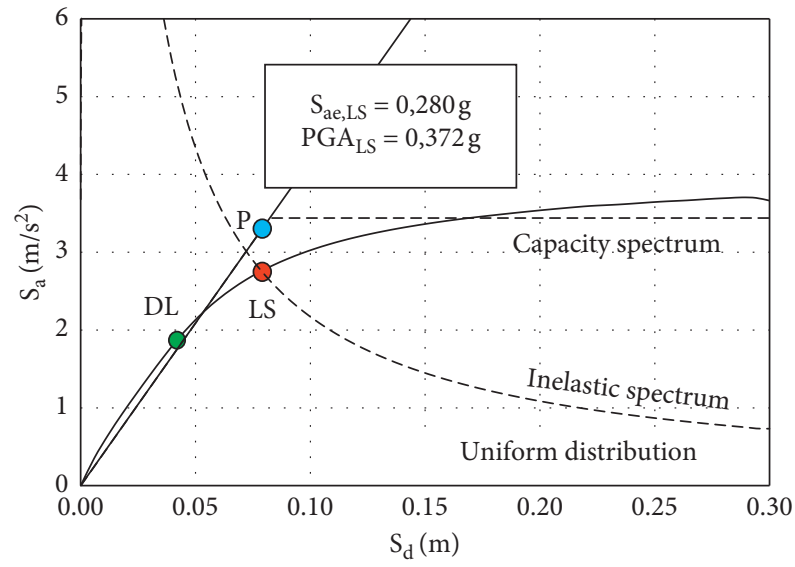

(a)

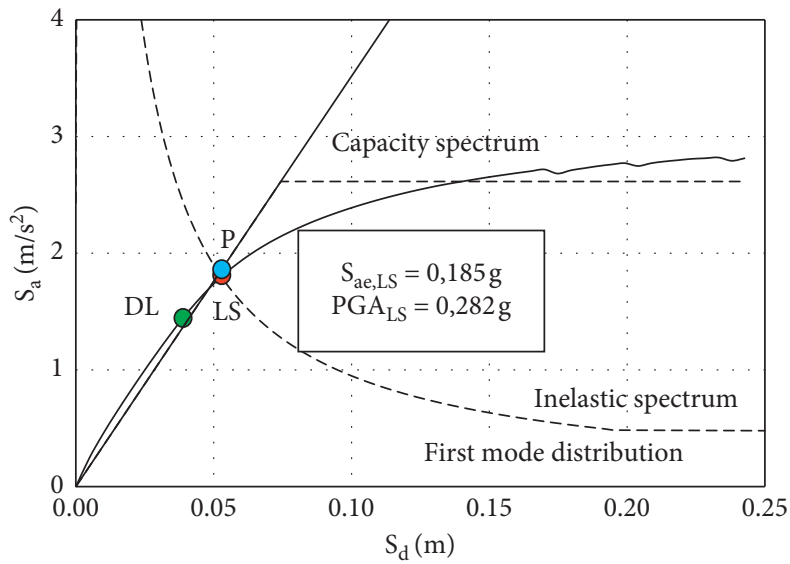

(b)

Figure 9: Demand vs. capacity comparison. The bare frame model with an accidental eccentricity of $10 \%$.

(LS) is defined by the corresponding chord rotation that is assumed as $3 / 4$ of the ultimate chord rotation $\theta_{u}$ defined by the formula A.1 from EN 1998-3 [63]. The results in Figures 6 and 7 show that there is no strength deterioration of pushover curves before the LS Limit State is reached. The reason for this behaviour is that the case studies considered here are frames infilled with fly ash bricks that are significantly softer and weaker in comparison to the RC frame. Moreover, the fly ash brick masonry infills have high deformability under cyclic actions and high deformation capacity. In fact, their hysteretic response during slow cyclic loading shows that the deformation capacity of the infills is about $2 \%$ of storey drift once infills start to deteriorate (Figure 2). Finally, in the case studies examined here, the LS Limit State occurs before the masonry infills significantly deteriorate. Figures 6 and 7, as well as Figures 8 and 9, also plot the elastoplastic idealization of the capacity spectrum; the radial line from origin and crossing yield point that represents the elastic system with period $T$; the inelastic displacement capacity $\left(S_{d, \text { LS}}\right)$ and the corresponding elastic spectral acceleration $\left(S_{a, L S}\right)$; and the Inelastic Demand Response Spectrum (IDRS). It can be observed that $P\left(S_{d, \mathrm{LS}}\right.$; $\left.S_{a, \mathrm{LS}}\right)$ is a point of the IN2 curve [62]. The corresponding peak ground acceleration $\left(\mathrm{PGA}_{\mathrm{LS}}\right)$ gives the ground motion intensity that leads the structure to its LS Limit State.

The values of the capacity PGA $\mathrm{LS}_{\mathrm{LS}}$ are shown in Table 2. For each case study (i.e., A-E), the values obtained for the infill frame model are compared with the values calculated for the bare frame model applying the EC8 [17] provisions for masonry infills. The case study $\mathrm{A}$ is regular in plan and elevation. Thus, no additional measures are required, and the results of the bare frame model are shown in Figure 8. For the case studies $\mathrm{C}, \mathrm{E}$, and $\mathrm{F}$, the irregularity in elevation does not give any amplification since the magnification factor $\eta$ is less than 1.1. Thus, the results are taken from the bare frame model with accidental eccentricity of 5\% (Figure 8 ). For the case studies $\mathrm{B}$ and $\mathrm{D}$, the irregularity in plan is considered by increasing the accidental eccentricity by a factor equal to 2.0. Thus, the results are obtained from the bare frame model with accidental eccentricity of $10 \%$ (Figure 9). In order to 
TAble 2: Capacity of Peak Ground Acceleration (PGA $A_{L S}$ ) at Life Safety (LS) Limit State.

\begin{tabular}{lcccc}
\hline Case study & \multicolumn{2}{c}{$\begin{array}{c}\text { Uniform distribution } \\
\text { Bare frame model with EC8 } \\
\text { measures for infilled frames }\end{array}$} & $\begin{array}{r}\text { First mode distribution } \\
\text { Infill frame model }\end{array}$ & $\begin{array}{r}\text { Bare frame model with EC8 } \\
\text { measures for infilled frames }\end{array}$ \\
\hline A & 0.730 & 0.665 & 0.532 & 0.523 \\
B & 0.456 & 0.372 & 0.338 & 0.282 \\
C & 0.190 & 0.665 & 0.520 & 0.523 \\
D & 0.677 & 0.372 & 0.408 & 0.282 \\
E & 0.638 & 0.665 & 0.540 & 0.523 \\
F & 0.615 & 0.665 & 0.528 & 0.523 \\
\hline
\end{tabular}

investigate the effect of masonry infill panels on the failure mechanism, Figures 10 and 11 show the patterns of yielding of the different case studies for their Life Safety performance level. These patterns of yielding are estimated in terms of chord rotation. The members where plasticity is developed (i.e., the chord rotation at yielding $\theta_{y}$ is reached) are plotted in red. The members where the chord rotation capacity at the Limit State of Life Safety is reached are plotted in black.

The results in Figures 10 and 11 show that in the case studies $\mathrm{A}, \mathrm{E}$, and $\mathrm{F}$ the patterns of yielding in the bare and infilled frame are very similar. After all, in these cases, no additional measures are required for infill irregularity, since $\mathrm{A}$ is regular in plan and elevation, while $\mathrm{E}$ and $\mathrm{F}$ are irregular in elevation, but the magnification factor $\eta$ of EC8 is less than 1.1. On the contrary, the masonry infills induce negative torsional effects if they are irregularly distributed in plan (such as in case studies B and D under the first mode distribution). In this case, the inelastic deformation demands concentrate on the "flexible" side of the building in which there are no masonry panels. Thus, the achieving of the chord rotation on a beam of the "flexible" side occurs for very low values of the target displacement (Figures 6 and 7). This behaviour is substantially reproduced by the bare frame model if the EC8 provisions for masonry infills are applied, that is, if the accidental eccentricity is increased by a factor equal to 2.0 (i.e., accidental eccentricity of 10\%) (Figure 9). The corresponding values of $\mathrm{PGA}_{\mathrm{LS}}$ in Table 2 are conservative when compared to the infilled frame model. This shows the effectiveness of the Eurocode 8 provision for the case studies with irregularities of infills in plan (i.e., cases B and D). Finally, it should be underlined that the results of case study $\mathrm{C}$ are particularly interesting. In this case, under the uniform distribution of lateral loads, the accidental eccentricity provides a torsional rotation of the building and this increases the stresses on infill panels placed in frame Y6 (see Figure 12). The masonry infill walls have a brittle behaviour and, thus, their contribution to the strength of frame Y6 decreases dramatically as the drift increases (Figure 13). This produces a sudden increase in stresses of the frame members that activates negative torsional effects since the inelastic deformation demands concentrate on the "flexible" side of a building (i.e., the part in which the failure of the masonry panels of frame Y6 occurs) (Figure 12). This high torsional rotation for low displacement values of control node does not occur both in the bare frame model and in the infill frame model under the first mode distribution. Thus, the capacity of the infill frame model for the uniform distribution $\left(\mathrm{PGA}_{\mathrm{LS}}=0.190 \mathrm{~g}\right)$ is significantly lower than both the value corresponding to the first mode distribution $\left(\mathrm{PGA}_{\mathrm{LS}}=0.520 \mathrm{~g}\right)$ and the value obtained using the bare frame model $\left(\mathrm{PGA}_{\mathrm{LS}}=0.665 \mathrm{~g}\right)$ (Table 2$)$. This means that, in this case, the masonry infills cannot be neglected in the model, since they significantly influence the inelastic response of the building and its failure mechanism. Thus, it is unsafe to neglect the presence of the masonry infills even in a case where the EC8 provisions are applied and no amplification is required.

Finally, the shear demand in the columns of infilled frames was investigated. In order to evaluate this effect, the total shear demand in a column $\left(V_{D, t}\right)$ was calculated as the sum of the shear force in the column resulting from the analysis $\left(V_{D, a}\right)$ and the additional shear force, which is induced by the masonry infill $\left(V_{D, i}\right)$ as follows:

$$
\begin{array}{r}
V_{D, t}=V_{D, a}+V_{D, i}, \\
V_{D, i}=\gamma_{c i} \cdot N_{s} \cdot \cos \theta,
\end{array}
$$

where $N_{s}$ is the axial force in the equivalent diagonal strut, $\theta$ is its inclination with respect to the horizontal axis, and $\gamma_{c i}$ is the model parameter that defines the proportion of the force that is transferred from the infill to the column. On the basis of the results of their parametric study, Celarec and Dolšek [13] observed that $\gamma_{c i}$ depends on the ratio between the stiffness of columns and that of the infills, as well as on the location of the column in the building varying from 0.44 to 0.58 . In this paper, the variation of $\gamma_{c i}$ due to the location of the column in the building was neglected, and the value 0.5 was considered. In the case studies examined, the ratio between the stiffness of columns and that of the infills is very high, since fly ash bricks were considered as infill, which are considerably softer and weaker compared to the RC frame [47]. Figure 14 shows, for example, the shear demand in the first storey corner column of frame Y1 (case study C) during the pushover analysis under the uniform distribution of lateral loads. Figure 14 shows that the shear force induced by the masonry infill is much less than the shear force in the column resulting from the analysis. Moreover, the failure of diagonals in compression always occurs before the LS Limit State of the RC structure, when the shear force in the column is still increasing with displacement. Thus, the increase of the shear demand in the columns induced by the masonry infill is very low. Finally, the total shear demand in the columns is well below the value of shear strength estimated according to Eurocode 8 [63]. For example, the shear strength is $327 \mathrm{kN}$ 
(a)

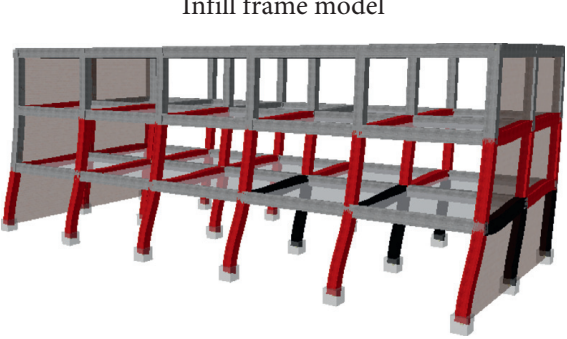

Bare frame model

EC8 measures for infilled frames

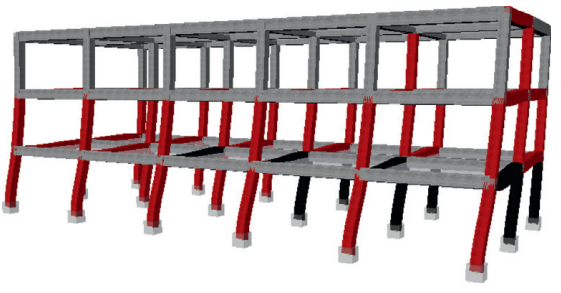

(b)
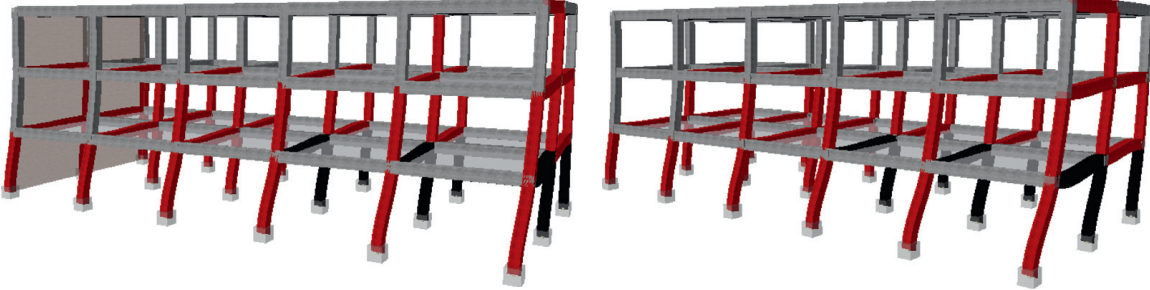

(c)
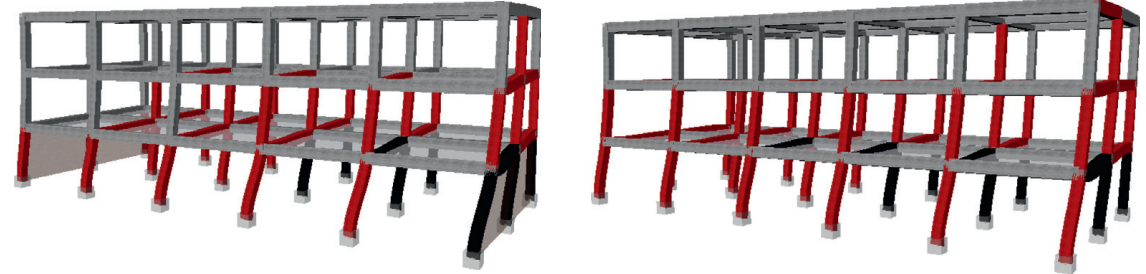

(d)
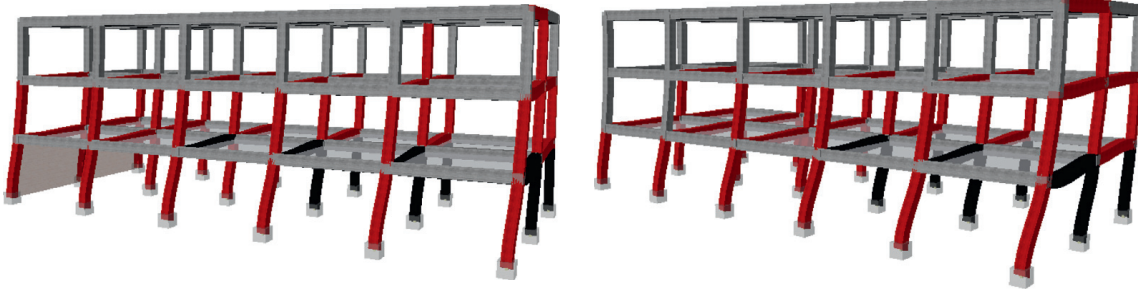

(e)
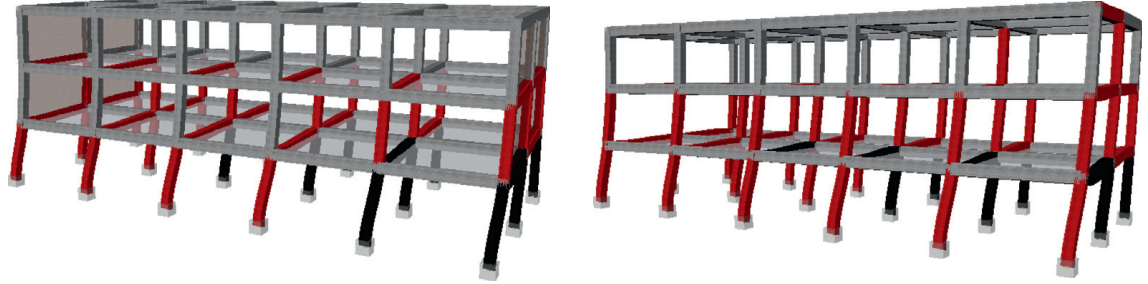

(f)
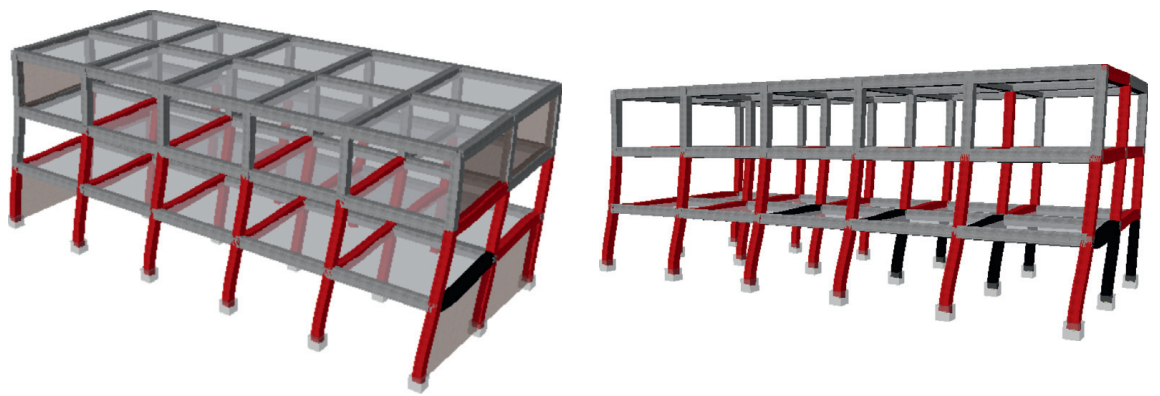

Figure 10: Comparison of patterns of yielding between the infill frame model and bare frame model. Life Safety Limit State-uniform distribution.

for the first storey corner column of frame Y1 considered in Figure 14. Figure 15 shows the total shear demand in the corner column of frame Y1 at the displacement corresponding to the Life Safety performance level of the infill frame model. The results of the infill frame model are compared to the results obtained from the bare frame model applying the additional EC8 measures for infilled frames. In the case study D, the shear demand in the column of the 
(a)

Infill frame model

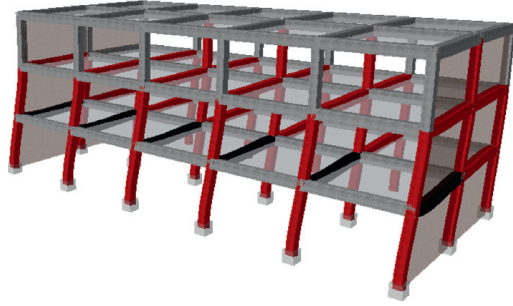

(b)

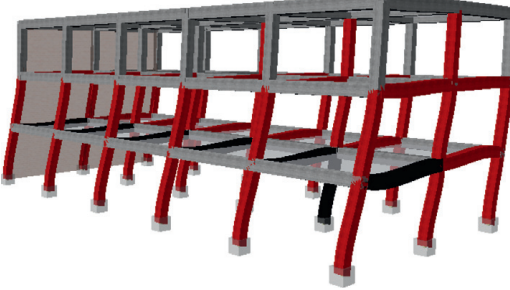

(c)

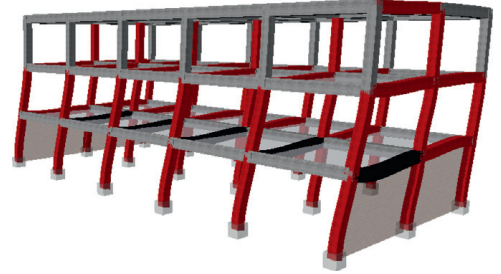

(d)

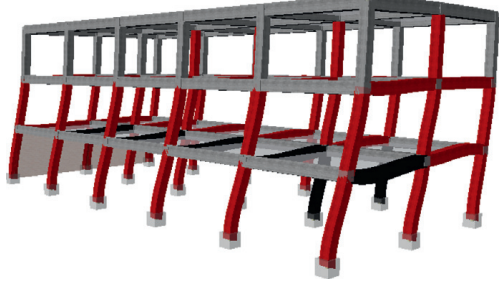

(e)

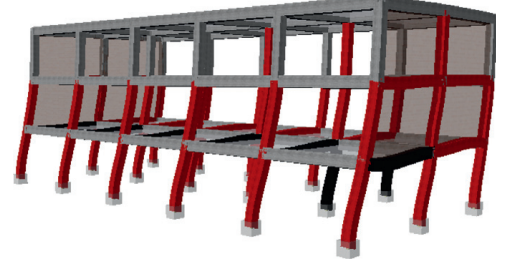

(f)

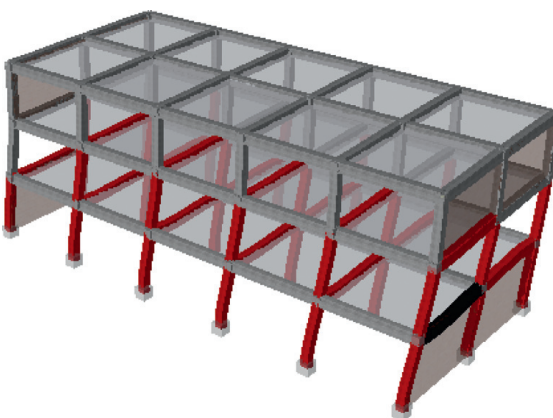

Bare frame model

EC8 measures for infilled frames
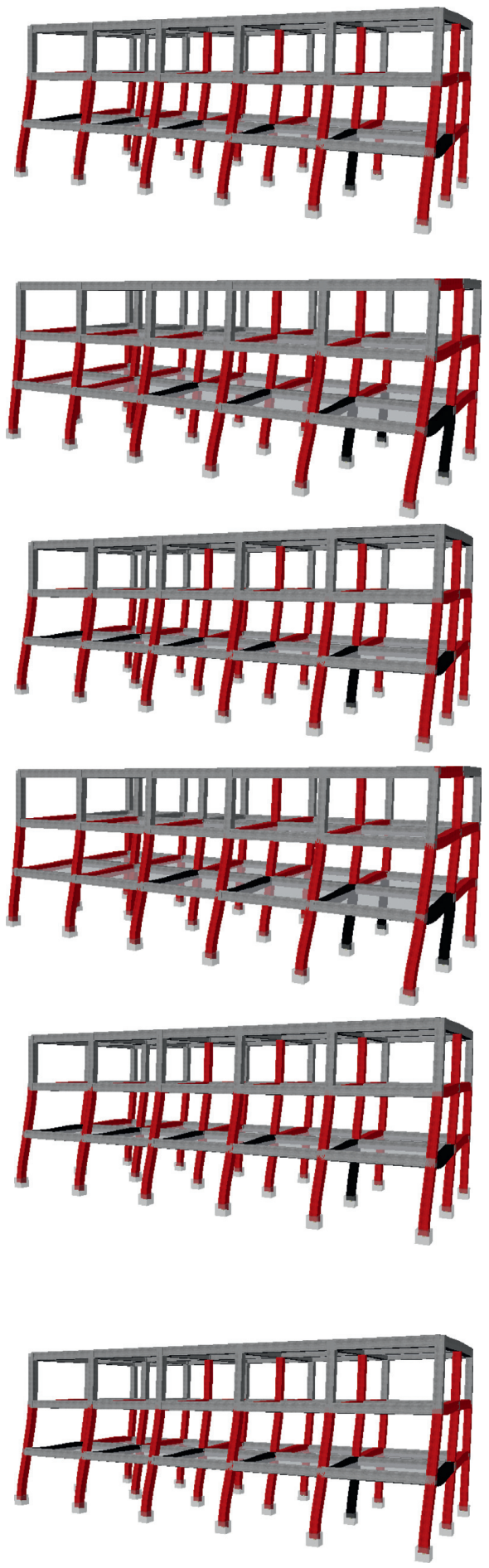

Figure 11: Comparison of patterns of yielding between the infill frame model and bare frame model. Life Safety Limit State-first mode distribution.

infilled frame model is greater than the bare frame model. At the upper storey, the increase of the shear demand in the columns of infilled frames reaches up to $30 \%$. This increase depends on the variation of nonlinear static response of the
$\mathrm{RC}$ frame due to the infill panels. Thus, for the case study D, the bare frame model is not conservative, also applying the Eurocode provisions to counteract the potential adverse effects depending on the infill irregularity in plan. 

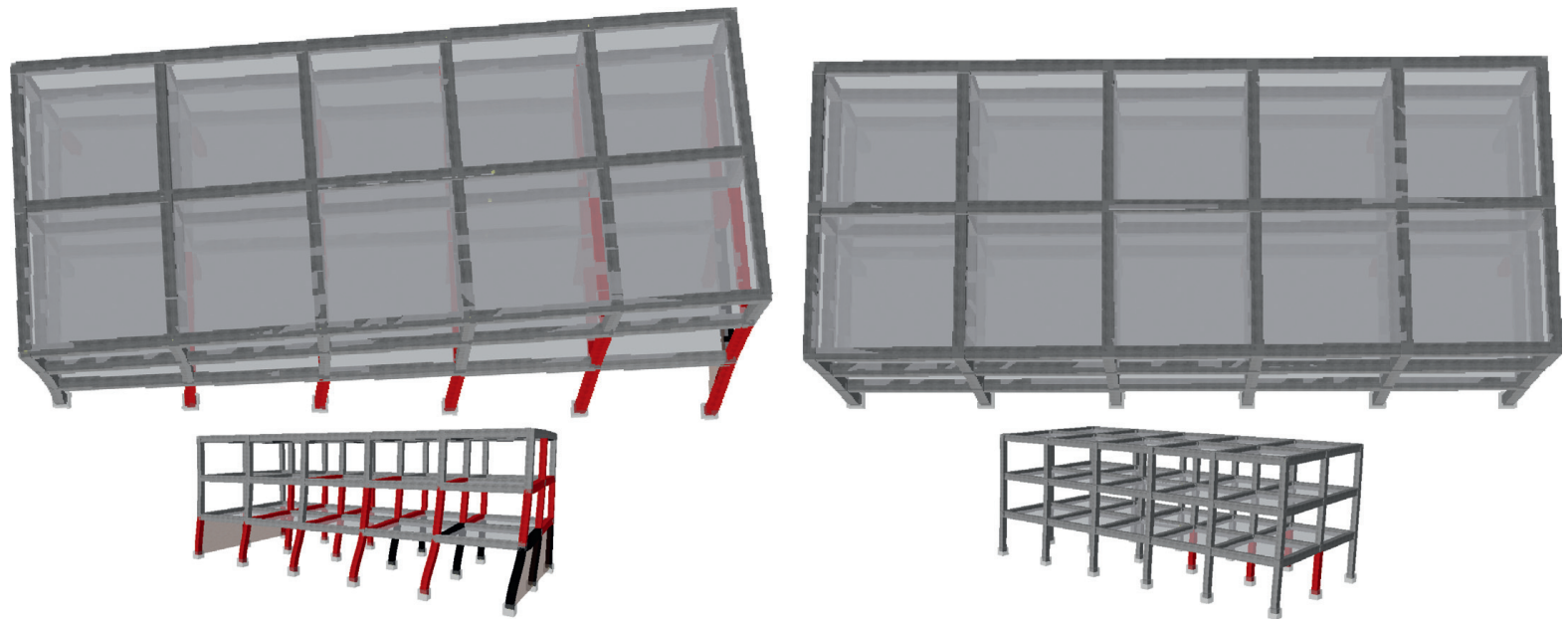

Figure 12: Comparison of deformed shape between the infill frame model and bare frame model. Target displacement at Life Safety Limit State of infill frame model-uniform distribution-case study C.

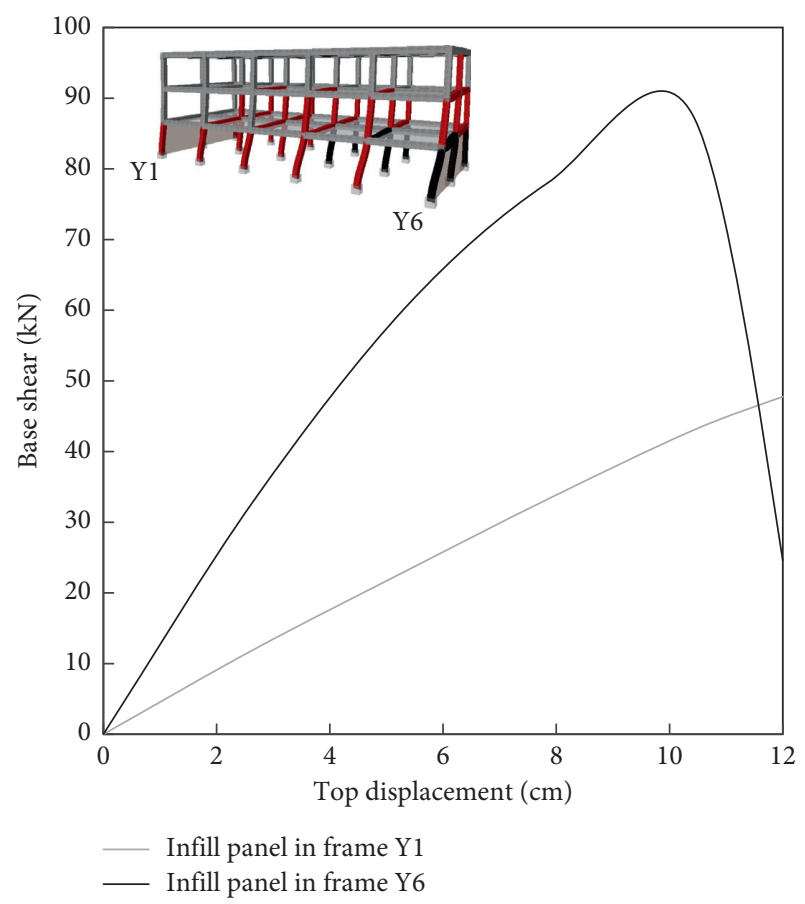

FIGURE 13: Base shear in infill panels vs. displacement of control node during pushover analysis under uniform distribution-case study C.

Finally, the influence of the masonry infills on the inelastic dynamic response of the buildings was evaluated using a set of 7 recorded accelerograms selected from the European Strong-Motion Database (ESD), the Italian Accelerometric Archive (ITACA), and the Selected Input Motions for Displacement-Based Assessment and Design database (SIMBAD) [64, 65]. The recorded accelerograms were adequately qualified with regard to the rules recommended in the seismic standards based on the target spectrum matching [17]. In the range of periods of interest

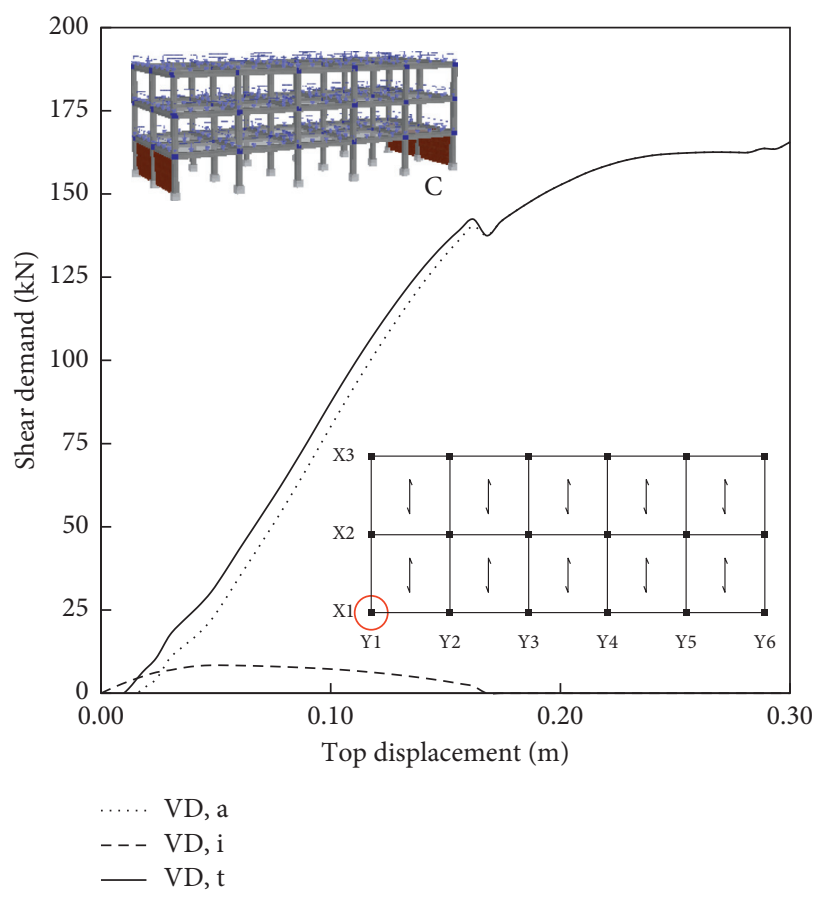

FIgURE 14: Shear demand in the corner column of frame Y1 during pushover analysis as the sum of the shear force in the column and the shear force induced by the masonry infill.

$(0.1 \leq T \leq 2.0 \mathrm{sec})$, no value of the mean elastic spectrum, calculated from all time histories, is less than $90 \%$ of the corresponding values of the target elastic spectrum. The recorded accelerograms considered in the numerical analysis are summarized in Table 3. The spectrum compatibility for the selected acceleration records is shown in Figure 16. The accelerograms considered in the analysis were scaled to $0.25 \mathrm{~g}$. The effects of an accidental eccentricity of $5 \%$ of the longer plan dimension were considered by shifting the centre of mass. In cases with irregularities in the distribution 


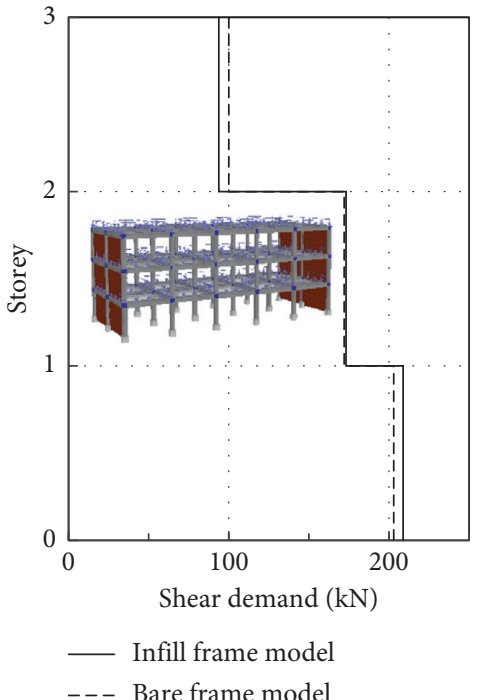

(a)

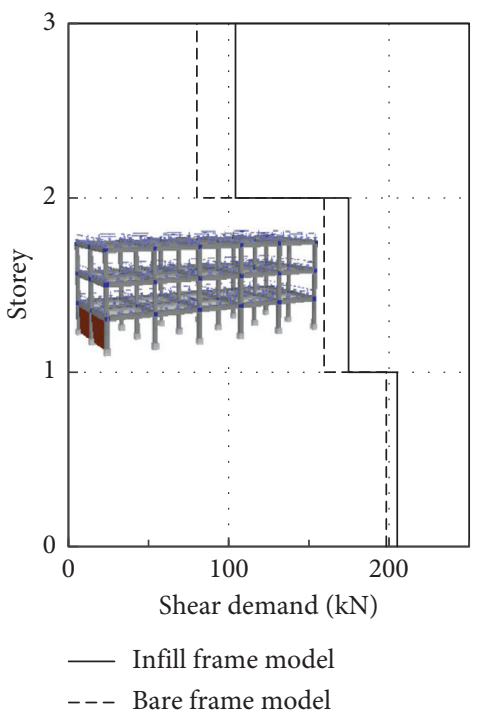

(d)

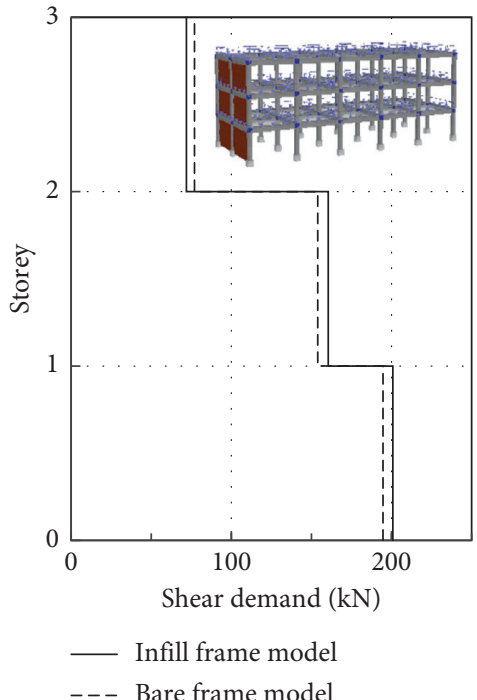

(b)

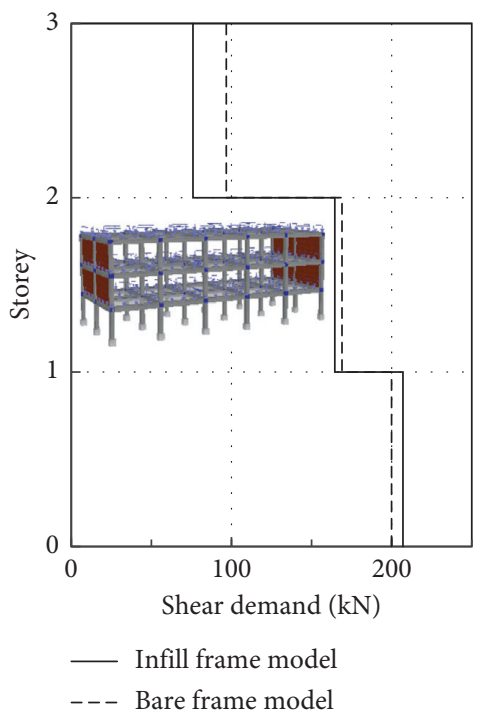

(e)

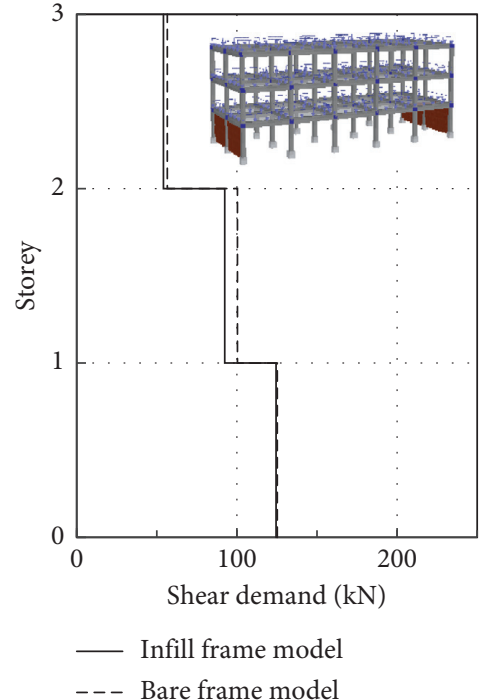

(c)

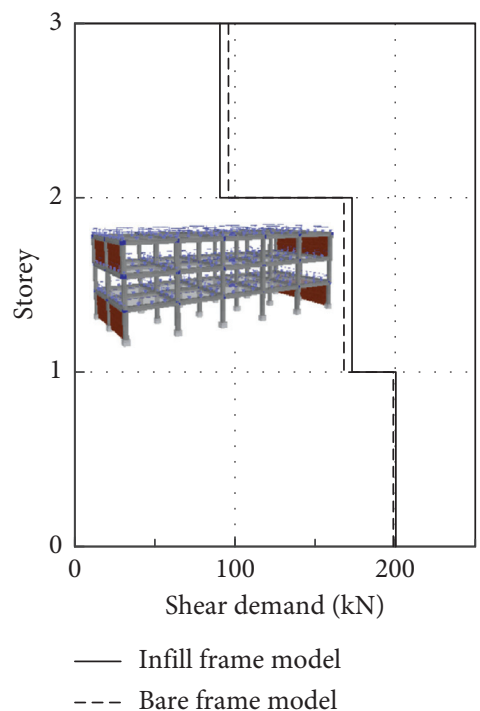

(f)

Figure 15: Shear demand in the corner column of frame Y1. Pushover analysis under uniform distribution.

TABLE 3: Set of earthquake natural records.

\begin{tabular}{lccccc}
\hline Waveform ID & Earthquake name & Date & Direction & PGA (m/s $\left.{ }^{2}\right)$ & Magnitude $(\mathrm{MW})$ \\
\hline $386 \mathrm{Y}$ & Christchurch & 13.06 .11 & EW & 5.546 & 6.0 \\
$467 \mathrm{X}$ & Kozani & 13.05 .95 & NS & 2.041 & 6.5 \\
$467 \mathrm{Y}$ & Kozani & 13.05 .95 & EW & 1.370 & 6.5 \\
$216 \mathrm{X}$ & Parkfield & 28.09 .04 & NS & 2.406 & 6.0 \\
$114 \mathrm{Y}$ & South Iceland & 17.06 .00 & EW & 1.559 & 6.5 \\
$452 \mathrm{Y}$ & Loma Prieta & 18.10 .89 & EW & 4.029 & 6.9 \\
$413 \mathrm{X}$ & Irpinia & 23.09 .80 & NS & 0.564 & 6.9 \\
\hline
\end{tabular}

of infills in plan, the accidental eccentricity was increased by a factor equal to 2.0 (accidental eccentricity of $10 \%$ ) according to EC8 provisions [17]. Figure 17 shows the mean of Y-top lateral displacements from Nonlinear Response
History Analysis. In the cases examined here, the bare frame model gives conservative results if the Eurocode 8 provisions for irregularities in the distribution of infills are applied. In fact, the displacements found using the bare frame model are 


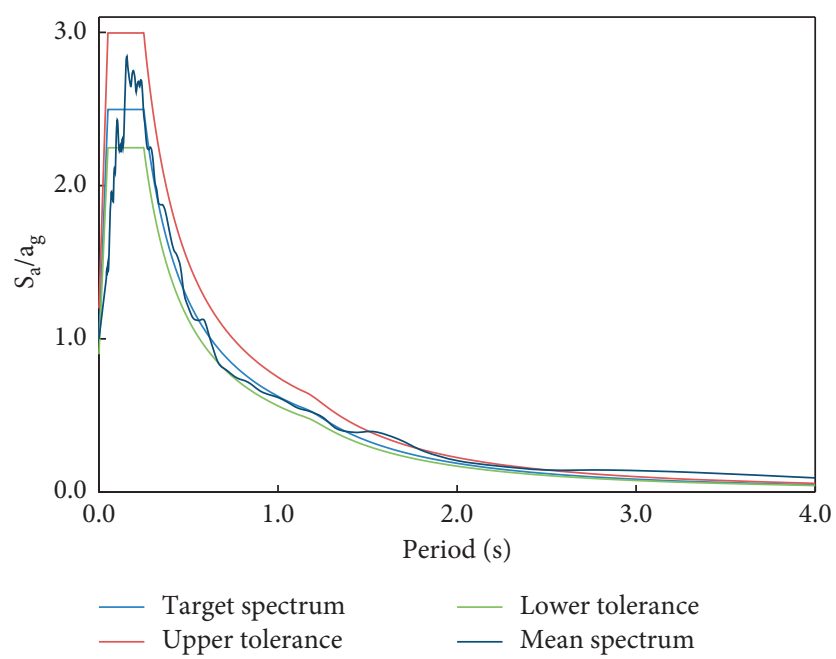

FIgURE 16: Spectrum compatibility for the selected records.

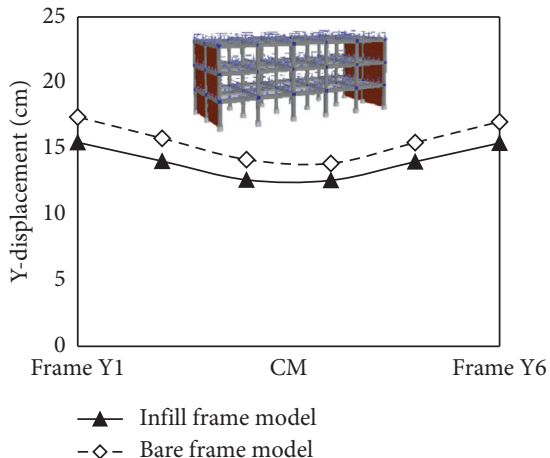

(a)

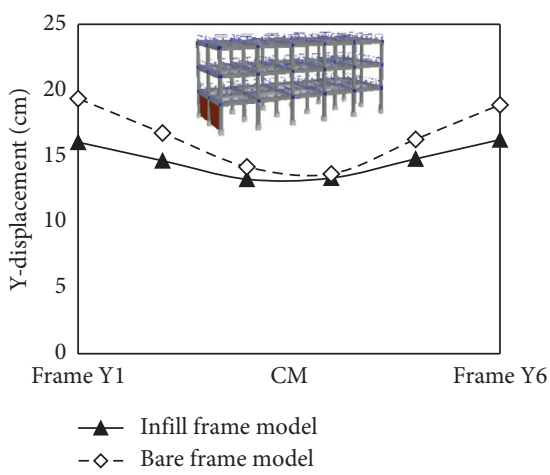

(d)

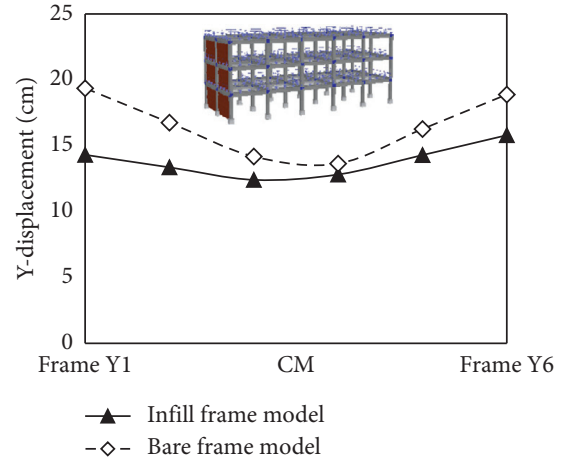

(b)

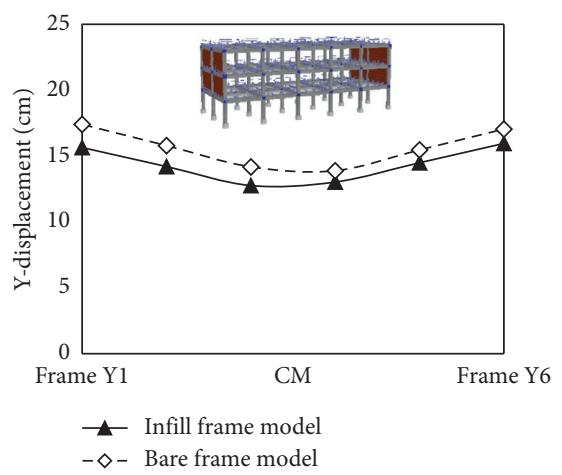

(e)

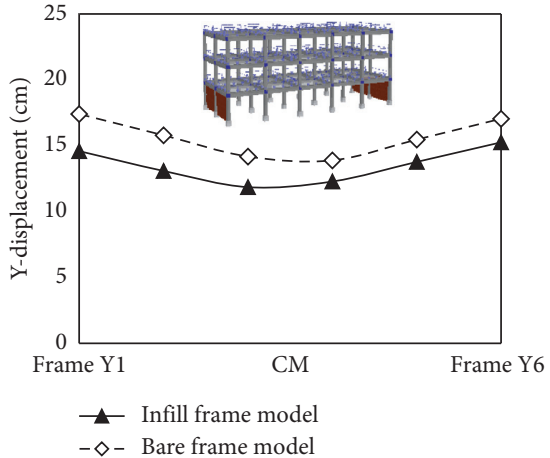

(c)

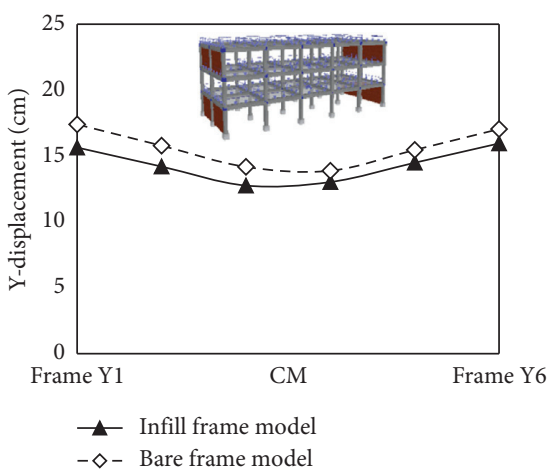

(f)

Figure 17: Mean of Y-top lateral displacements from Nonlinear Response History Analysis.

higher than those obtained with the more refined infill frame model, both in the centre of mass (CM) and in the left (frame Y1) and right (frame Y6) sides.

\section{Conclusions}

This paper investigates the effectiveness of the Eurocode 8 design provisions for infill irregularity. For this purpose, the paper addresses some marginal cases for which Eurocode 8 does not require any measures for infilled frames or the additional measures are not mandatory. To this aim, a macromodel that considers both frictional effects and local infill-frame interaction is used for the masonry infill panels while inelastic force-based fibre elements are used for the RC members. The inelastic response of the structure is estimated using both nonlinear static (pushover) and Nonlinear Response History Analysis. The total shear demand on the columns is calculated as the sum of the shear force in the column resulting from the analysis and the additional shear force that is induced by the masonry infill. 
This study has led to the following conclusions:

(1) Masonry infills may significantly alter the inelastic response of the building even if they are regularly distributed both in plan and elevation, or the Eurocode 8 provisions to counteract the effect of irregular distribution of masonry infill panels are applied. In fact, different structural failures due to torsion and soft-storey effects are highlighted.

(2) In one of the case studies examined here (in which the distribution of masonry infills is regular in plan and irregular in elevation), the torsional rotation of the building due to the accidental eccentricity increases the stresses on infill panels placed on one side of the plan. The brittle behaviour of these panels dramatically decreases their contribution in strength and increases the stresses of the frame members, thus activating torsion and soft-storey effects.

(3) The abovementioned unwanted inelastic behaviour of the infilled frame model does not occur in the bare frame model. Thus, the capacity, in terms of peak ground acceleration, of the bare frame model is greater than that one obtained with the infill frame model. This means that in one of the case studies examined here it is not conservative to neglect the participation of the infill panels in the overall structural behaviour, even in a case where the EC8 provisions are considered, and no additional measures are required.

(4) Even in cases in which the Eurocode 8 provisions against the negative effects of infills are not mandatory but are applied, a significant increase in shear demand of columns may occur. This increase is given by both the additional shear demand due to the local frame-infill interaction and the variation of the nonlinear response of the framed structure due to the masonry infills. The increase of the shear demand in the columns may cause their brittle shear failure if they are not seismically designed and detailed. Thus, the masonry infill may give an adverse contribution that may induce unexpected and dangerous nonductile collapse mechanisms.

(5) Finally, it should be underlined that some simplifying hypotheses have been introduced in the present paper. First of all, the out-of-plane failure of infills was neglected, while it can introduce irregularities in the distribution of infills in plan and elevation, thus affecting in a negative way the seismic behaviour of the building. Then, only infills without openings were considered in the analysis. Moreover, the potential shear failure of the columns was not modelled, but it was checked that the shear demand did not exceed the shear capacity. Finally, the specific Eurocode 8 provisions to counteract the potential adverse effects depending on plan and elevation regularity of the masonry infills were considered in the analysis.

\section{Data Availability}

The data used to support the findings of this study are available from the corresponding author upon request.

\section{Conflicts of Interest}

The authors declare that they have no conflicts of interest regarding the publication of this paper.

\section{Acknowledgments}

This work was financially supported by the research project RELUIS 2014-2018 "Steel and Composite Steel-Concrete Structures" issued by the Italian "Protezione Civile."

\section{References}

[1] A. Furtado, H. Rodrigues, and A. Arede, "Modelling of masonry infill walls participation in the seismic behaviour of RC buildings using OpenSees," International Journal of Advanced Structural Engineering (IJASE), vol. 7, no. 2, pp. 117-127, 2015.

[2] M. Dolsek and P. Fajfar, "Mathematical modelling of an infilled RC frame structure based on the results of pseudodynamic tests," Earthquake Engineering and Structural Dynamics, vol. 31, pp. 1215-1230, 2002.

[3] M. Ferraioli, "Case study of seismic performance assessment of irregular RC buildings: hospital structure of Avezzano (L'Aquila, Italy)," Earthquake Engineering and Engineering Vibration, vol. 14, no. 1, pp. 141-156, 2015.

[4] M. Ferraioli, "Inelastic torsional response of an asymmetricplan hospital building in Italy," in COST ACTION C26: Urban Habitat Constructions under Catastrophic Events-Proceedings of the Final Conference, pp. 365-370, CRC Press, Boca Raton, FL, USA, 2010.

[5] A. B. Mehrabi, P. Benson Shing, M. P. Schuller, and J. L. Noland, "Experimental evaluation of masonry-infilled RC frames," Journal of Structural Engineering, vol. 122, no. 3, pp. 228-237, 1996.

[6] T. B. Panagiotakos and M. N. Fardis, "Seismic response of infilled RC frames structures," in Proceedings of the, XXI World Conference of Earthquake Engineering, Acapulco, Mexico, February 1996.

[7] M. Dolsek and P. Fajfar, "The effect of masonry infills on the seismic response of a four storey reinforced concrete frame-a probabilistic assessment," Engineering Structures, vol. 30, no. 11, pp. 3186-3192, 2008.

[8] G. Uva, D. Raffaele, F. Porco, and A. Fiore, "On the role of equivalent strut models in the seismic assessment of infilled RC buildings," Engineering Structures, vol. 42, pp. 83-94, 2012.

[9] A. Fiore, F. Porco, D. Raffaele, and G. Uva, "About the influence of the infill panels over the collapse mechanisms actived under pushover analyses: two case studies," Soil Dynamics and Earthquake Engineering, vol. 39, pp. 11-22, 2012.

[10] Y. P. Yuen and J. S. Kuang, "Nonlinear seismic responses and lateral force transfer mechanisms of RC frames with different infill configurations," Engineering Structures, vol. 91, pp. 125-140, 2015. 
[11] G. Mondal and S. Tesfamariam, "Effects of vertical irregularity and thickness of unreinforced masonry infill on the robustness of RC framed buildings," Earthquake Engineering and Structural Dynamics, vol. 43, no. 2, pp. 205-223, 2014.

[12] P. G. Asteris, S. T. Antoniou, D. S. Sophianopoulos, and C. Z. Chrysostomou, "Mathematical macromodeling of infilled frames: state of the art," Journal of Structural Engineering, vol. 137, no. 12, pp. 1508-1517, 2011.

[13] D. Celarec and M. Dolšek, "Practice-oriented probabilistic seismic performance assessment of infilled frames with consideration of shear failure of columns," Earthquake Engineering \& Structural Dynamics, vol. 42, no. 9, pp. 1339-1360, 2013.

[14] L. Cavaleri and F. Di Trapani, "Cyclic response of masonry infilled RC frames: experimental results and simplified modeling," Soil Dynamics and Earthquake Engineering, vol. 65, pp. 224-242, 2014.

[15] A. F. Mohammad, M. Faggella, R. Gigliotti, and E. Spacone, "Seismic performance of older R/C frame structures accounting for infills-induced shear failure of columns," Engineering Structures, vol. 122, pp. 1-13, 2016.

[16] S. H. Basha and H. B. Kaushik, "A novel macromodel for prediction of shear failure in columns of masonry infilled RC frames under earthquake loading," Bulletin of Earthquake Engineering, vol. 17, no. 4, pp. 2219-2244, 2019.

[17] CEN European Standard EN1998-1, "Eurocode 8: Design of Structures for Earthquake Resistance," in Part 1: General Rules, Seismic Action and Rules for Buildings, European Committee for Standardisation, Brussels, China, 2004.

[18] M. N. Fardis, "Design Provisions for Masonry-Infilled RC Frames," in Proceedings of the 12th World Conference on Earthquake Engineering, Auckland, New Zealand, January 2000.

[19] M. Dolšek and P. Fajfar, "The effect of masonry infills on the seismic response of a four-storey reinforced concrete frame-a deterministic assessment," Engineering Structures, vol. 30, no. 7, pp. 1991-2001, 2008.

[20] NTC-2018 Guidelines, "Technical standards for constructions," Official Journal of the Italian Republic, vol. 20, 2018.

[21] NTC-Instruction 2019, "Instructions for the application of the new technical norms on constructions (in Italian)," Official Journal of the Italian Republic, vol. 7, 2019.

[22] Federal Emergency Management Agency (FEMA), NEHRP Guidelines for the Seismic Rehabilitation of Buildings, FEMA273, Washington, DC, USA, 1997.

[23] Federal Emergency Management Agency (FEMA), NEHRP Commentary on the Guidelines for the Seismic Rehabilitation of Buildings, FEMA-274, Washington, DC, USA, 1997.

[24] Applied Technology Council (ATC), "Seismic Evaluation and Retrofit of Concrete Buildings,” Report No. ATC-40, Applied Technology Council, Redwood City, CA, USA, 1996.

[25] R. J. Mainstone, Supplementary Note on the Stiffness and Strength of Infilled Frames, Building Research Establishment, London, UK, 1974.

[26] Federal Emergency Management Agency (FEMA), Prestandard and Commentary for the Seismic Rehabilitation of Buildings, FEMA 356, Washington, DC, USA, 2000.

[27] S. V. Polyakov, "On the interaction between masonry filler walls and enclosing frame when loading in the plane of the wall," in Translation in Earthquake Engineering, pp. 36-42, Earthquake Engineering Research Institute, San Francisco, CA, USA, 1960.
[28] M. Holmes, "Steel frames with brickwork and concrete infilling," Proceedings of the Institution of Civil Engineers, vol. 19, no. 4, pp. 473-478, 1961.

[29] B. S. Smith, "Lateral stiffness of infilled frames," Journal of Structural Division, vol. 88, no. 6, pp. 183-199, 1962.

[30] Federal Emergency Management Agency (FEMA), Evaluation of earthquake damaged concrete and masonry wall buildings: basic procedures manual, FEMA-306, Washington, DC, USA, 1998.

[31] R. E. Klingner and V. V. Bertero, "Earthquake resistance of infilled frames," Journal of Structural Division, vol. 104, no. 6, pp. 973-989, 1978.

[32] P. G. Asteris, D. M. Cotsovos, C. Z. Chrysostomou, A. Mohebkhah, and G. K. Al-Chaar, "Mathematical micromodelling of infilled frames: state of the art," Engineering Structures, vol. 56, pp. 1905-1921, 2013.

[33] F. J. Crisafulli, A. J. Carr, and R. Park, "Analytical modelling of infilled frame structures," Bulletin of the New Zealand Society for Earthquake Engineering, vol. 33, no. 1, pp. 30-47, 2000.

[34] A. Saneinejad and B. Hobbs, "Inelastic design of infilled frames," Journal of Structural Engineering, vol. 121, no. 4, pp. 634-650, 1995.

[35] A. Madan, A. M. Reinhorn, J. B. Mander, and R. E. Valles, "Modeling of masonry infill panels for structural analysis," Journal of Structural Engineering, vol. 123, no. 10, pp. 12951302, 1997.

[36] F. J. Crisafulli, "Seismic behaviour of reinforced concrete structures with masonry infills," $\mathrm{PhD}$ Thesis, University of Canterbury, Christchurch, New Zealand, 1997.

[37] F. J. Crisafulli and A. J. Carr, "Proposed macro-model for the analysis of infilled frame structures," Bulletin of the New Zealand Society for Earthquake Engineering, vol. 40, no. 2, pp. 69-77, 2007.

[38] W. W. El-Dakhakhni, M. Elgaaly, and A. A. Hamid, "Threestrut model for concrete masonry-infilled steel frames," Journal of Structural Engineering, vol. 129, no. 2, pp. 177-185, 2003.

[39] L. Cavaleri, M. Fossetti, and M. Papia, "Infilled frames: developments in the evaluation of cyclic behaviour under lateral loads," Structural Engineering and Mechanics, vol. 21, no. 4, pp. 469-494, 2005.

[40] S. H. Basha and H. B. Kaushik, "Behavior and failure mechanisms of masonry-infilled RC frames (in low-rise buildings) subject to lateral loading," Engineering Structures, vol. 111, pp. 233-245, 2016.

[41] SeismoStruct, "A computer program for static and dynamic analysis for framed structures," 2018, http://www.seismosoft. com.

[42] E. Smyrou, C. Blandon, S. Antoniou, R. Pinho, and F. Crisafulli, "Implementation and verification of a masonry panel model for nonlinear dynamic analysis of infilled RC frames," Bulletin of Earthquake Engineering, vol. 9, no. 5, pp. 1519-1534, 2011.

[43] M. L. Moretti, T. Papatheocharis, and P. C. Perdikaris, "Design of reinforced concrete infilled frames," Journal of Structural Engineering ASCE, vol. 140, no. 9, Article ID 04014062, 2014.

[44] D. D’Ayala, J. Worth, and O. Riddle, "Realistic shear capacity assessment of infill frames: comparison of two numerical procedures," Engineering Structures, vol. 31, no. 8, pp. 1745-1761, 2009.

[45] D. J. Kakaletsis and C. G. Karayannis, "Influence of masonry strength and openings on infilled $\mathrm{R} / \mathrm{C}$ frames under cycling 
loading," Journal of Earthquake Engineering, vol. 12, no. 2, pp. 197-221, 2008.

[46] J. Zovkic, V. Sigmund, and I. Guljas, "Cyclic testing of a single bay reinforced concrete frames with various types of masonry infill," Earthquake Engineering \& Structural Dynamics, vol. 42, no. 8, pp. 1131-1149, 2013.

[47] S. H. Basha and H. B. Kaushik, "Suitability of fly ash brick masonry as infill in reinforced concrete frames," Materials and Structures, vol. 49, no. 9, pp. 3831-3845, 2016.

[48] M. Preti, N. Bettini, and G. Plizzari, "Infill walls with sliding joints to limit infill-frame seismic interaction: large-scale experimental test," Journal of Earthquake Engineering, vol. 16, no. 1, pp. 125-141, 2012.

[49] D. Markulak, I. Radić, and V. Sigmund, "Cyclic testing of single bay steel frames with various types of masonry infill," Engineering Structures, vol. 51, pp. 267-277, 2013.

[50] J. B. Mander, M. J. N. Priestley, and R. Park, "Theoretical stress-strain model for confined concrete," Journal of Structural Engineering, vol. 114, no. 8, pp. 1804-1826, 1988.

[51] A. K. Chopra and R. K. Goel, "A modal pushover analysis procedure for estimating seismic demands for buildings," Earthquake Engineering \& Structural Dynamics, vol. 31, no. 3, pp. 561-582, 2002.

[52] M. Kreslin and P. Fajfar, "The extended N2 method considering higher mode effects in both plan and elevation," Bulletin of Earthquake Engineering, vol. 10, no. 2, pp. 695-715, 2012.

[53] H. Sucuoğlu and M. S. Günay, "Generalized force vectors for multi-mode pushover analysis," Earthquake Engineering \& Structural Dynamics, vol. 40, no. 1, pp. 55-74, 2011.

[54] M. Ferraioli, "Multi-mode pushover procedure for deformation demand estimates of steel moment-resisting frames," International Journal of Steel Structures, vol. 17, no. 2, pp. 653-676, 2017.

[55] M. Ferraioli, A. Lavino, and A. Mandara, "Effectiveness of multi-mode pushover analysis procedure for the estimation of seismic demands of steel moment frames," Ingegneria Sismica, vol. 35, no. 2, pp. 78-90, 2018.

[56] S. Antoniou and R. Pinho, "Development and verification of a displacement-based adaptive pushover procedure," Journal of Earthquake Engineering, vol. 8, no. 5, pp. 643-661, 2004.

[57] E. Kalkan and S. K. Kunnath, "Adaptive modal combination procedure for nonlinear static analysis of building structures," Journal of Structural Engineering, vol. 132, no. 11, pp. 17211731, 2006.

[58] M. Ferraioli, A. Lavino, and A. Mandara, "An adaptive capacity spectrum method for estimating seismic response of steel moment-resisting frames," Ingegneria Sismica, vol. 33, no. 1-2, pp. 47-60, 2016.

[59] M. Dolsek and P. Fajfar, "Simplified non-linear seismic analysis of infilled reinforced concrete frames," Earthquake Engineering \& Structural Dynamics, vol. 34, no. 1, pp. 49-66, 2005.

[60] P. Fajfar, "Capacity spectrum method based on inelastic demand spectra," Earthquake Engineering \& Structural Dynamics, vol. 28, no. 9, pp. 979-993, 1999.

[61] T. Vidic, P. Fajfar, and M. Fischinger, "Consistent inelastic design spectra: strength and displacement," Earthquake Engineering \& Structural Dynamics, vol. 23, p. 502-521, 1994.

[62] M. Dolšek and P. Fajfar, "IN2-a simple alternative for IDA," in Proceedings of the 13th World Conference on Earthquake Engineering, Paper No. 3353, Vancouver, Canada, August 2004.
[63] CEN European Standard EN1998-3, Eurocode 8 - Design of Structures for Earthquake Resistance-Part 3: Assessment and Retrofitting of Buildings, European Committee for Normalization, Brussels, China, 2005.

[64] I. Iervolino, C. Galasso, and E. Cosenza, "REXEL: computer aided record selection for code-based seismic structural analysis," Bulletin of Earthquake Engineering, vol. 8, no. 2, pp. 339-362, 2010.

[65] C. Smerzini and R. Paolucci, "Research Project DPC-RELUIS 2010-2013," in SIMBAD: A Database with Selected Input Motions for Displacement-Based Assessment and Design-2nd Release, Department of Structural Engineering, Politecnico di Milano, Milan, Italy, 2011. 